\title{
Corporate Social Responsibility Reporting in China: Symbol or Substance?
}

\author{
Christopher Marquis \\ Harvard Business School, Boston, Massachusetts 02163, cmarquis@hbs.edu \\ Cuili Qian \\ Department of Management, City University of Hong Kong, Kowloon, Hong Kong SAR, cuili.qian@cityu.edu.hk
}

\begin{abstract}
$\mathrm{T}^{\mathrm{s}}$ his study focuses on how and why firms strategically respond to government signals on appropriate corporate activity. We integrate institutional theory with research on corporate political strategy to develop a political dependence model that explains (a) how different types of dependency on the government lead firms to issue corporate social responsibility (CSR) reports and (b) how the risk of governmental monitoring affects the extent to which CSR reports are symbolic or substantive. First, we examine how firm characteristics reflecting dependence on the government-including private versus state ownership, executives serving on political councils, political legacy, and financial resources-affect the likelihood of firms issuing CSR reports. Second, we focus on the symbolic nature of CSR reporting and how variance in the risk of government monitoring through channels such as bureaucratic embeddedness and regional government institutional development influences the extent to which CSR communications are symbolically decoupled from substantive CSR activities. Our database includes all CSR reports issued by the approximately 1,600 publicly listed Chinese firms between 2006 and 2009. Our hypotheses are generally supported. The political perspective we develop contributes to organizational theory by showing that (a) government signaling is an important mechanism of political influence, (b) different types of dependency on the government expose firms to different types of legitimacy pressure, and (c) firms face a decoupling risk that makes them more likely to enact substantive CSR actions in situations in which they are likely to be monitored.
\end{abstract}

Key words: institutional theory; political strategy; nonmarket strategy; emerging markets; China; corporate social responsibility

History: Published online in Articles in Advance July 29, 2013.

\section{Introduction}

The implications and antecedents of firms' political strategies have emerged as important areas of research in organizational theory (Bonardi et al. 2005, Hillman et al. 2004). Governments control critical resources that shape firms' competitive positions, for example, through regulations affecting an industry or through tax policies favoring certain regions (Baron 1995, Schuler and Rehbein 1997). Scholars have identified a number of ways that firms act strategically in managing their relationships with governmental actors, including political activities such as lobbying, establishing political action committees (PACs), and advocacy or testimony on key issues (Hillman 2003, Hillman et al. 2004, Lord 2000, Mizruchi 1992, Quasney 2003). Whereas this research has focused on how firms work to actively shape government rule-making processes, other research has shown that in addition to setting rules and engaging in coercive processes, governments also use signaling processes to create norms and standards of legitimacy for firms (Dobbin and Sutton 1998; Dobbin et al. 1993; Edelman 1990, 1992). Yet research on corporate political strategy has not, to our knowledge, addressed how and why firms respond strategically to government signals.
In this paper, we investigate the factors that render a firm more or less likely to adhere to government signals in an effort to shape perceptions of its political legitimacy, which we define as the extent to which the government views the firm's actions as being in accordance with norms and laws. Consistent with work on corporate political strategy proposing that firms seek present or future resources from governments, we view political legitimacy, which is associated with greater access to government resources, as a strategic resource for firms (Hillman 2005, Li and Zhang 2007, Peng and Luo 2000, Pfeffer and Salancik 1978). Furthermore, this resource may be especially important in emerging economies where weak formal institutions can lead firms to rely more on informal mechanisms (La Porta et al. 1998, Peng and Heath 1996). The political response model we develop focuses on two key factors that shape a firm's response to government signals: political dependence and government monitoring.

If adhering to government signals results from a firm's desire to appear more legitimate to the government, then it is important to recognize that firms vary in their dependence on governmental actors and that this variation should influence their responses to 
government signals. Specifically, we examine how key features of a firm's political embeddedness that shape its need for legitimacy-e.g., state versus private ownership (Chen 2007, Li and Zhang 2007), network connections to national political congresses (Hillman 2005, Ma and Parish 2006), political legacy (Kriauciunas and Kale 2006, Marquis and Huang 2010), and financial resources-result in firms being more or less likely to follow government signals.

However, research has also found that such legitimacy pressures can result in decoupling processes whereby corporate responses to external demands vary in the extent to which they are symbolic or substantive (Meyer and Rowan 1977, Okhmatovskiy and David 2012, Oliver 1991). In this paper, we also explore the extent to which symbolic action in response to government signals depends on the likelihood of a firm being monitored by governmental actors. Research on decoupling has shown that the implementation of symbolic strategies is typically not monitored by stakeholders (Zajac and Westphal 2004). We introduce the notion that firms face a "decoupling risk" if they respond only symbolically to government signals: exposure of the decoupling may harm the firm. Specifically, we argue that a combination of (a) a firm's bureaucratic embeddedness, i.e., its network connections within the government bureaucracy as opposed to its connections to national congresses (Fan et al. 2007), and (b) regional government institutional development (Brandt and Li 2003, Goldstein 1995) subject the firm to more government monitoring. We focus on why highly monitored firms that are at greater risk of having symbolic action exposed are more likely to adhere substantively to government signals. Figure 1 describes the general model we propose and the context-specific factors that we elaborate in our hypotheses below.
Our empirical context is the introduction and spread of corporate social responsibility (CSR) reporting among all publicly listed Chinese firms from 2006 to 2009. This context is in many ways ideal to study the issues of interest. First, it is an activity that the Chinese government has been actively signaling to firms as legitimate and important. Since 2006, when China's 11th Five-Year Plan initiated the idea that China should pursue a more "harmonious society," the central government has issued a number of CSR reporting guidelines for large firms as a strategy to help balance China's extensive economic growth with the social and environmental effects of that growth (See 2009). It is important to note that these governmental issuances are not specific laws or mandates but are examples of a government signaling what it considers to be an important area of corporate focus.

As of 2009, Chinese firms issued over $15 \%$ of the world's CSR reports, yet there is significant variation across Chinese firms in the amount of information disclosed on specific CSR activities (China WTO Tribune 2009). This variation allows us to determine the extent to which the reports are purely symbolic exercises or indicative of substantive CSR activities. In the political economy of China, significant state ownership of many firms and the extensive and varied connections between the government and large firms allow us to examine how the effect of government signaling varies depending on the degree of direct government control. Furthermore, the extensive data available on these publicly listed firms allow us to statistically control for other potential explanations such as variations across industries and pressures from international shareholders and consumers.

Our paper makes a number of contributions to organizational theory. First, we show how dependence and monitoring create variations in firms' strategic adherence to government signals about legitimate activities;

Figure 1 A General Model of Firm Response to Government Signals with Application to CSR Reporting in China

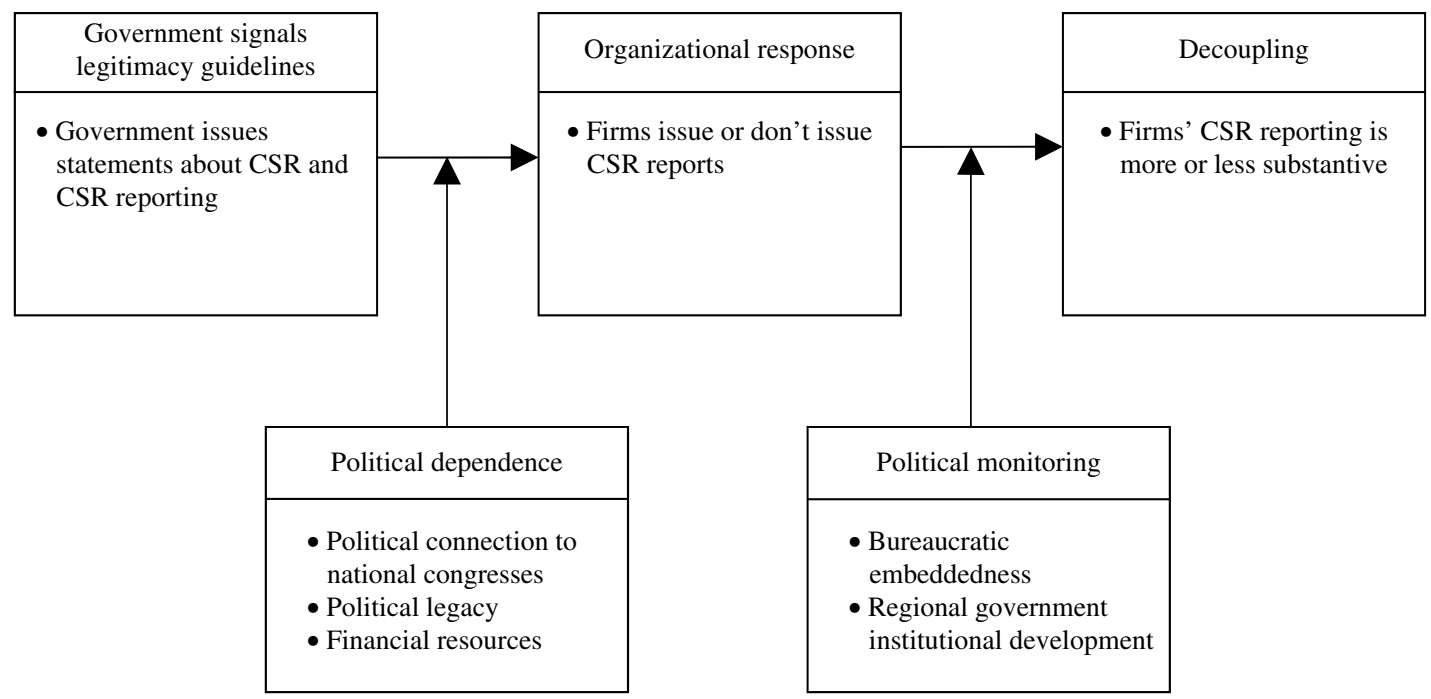


we thus integrate neoinstitutional insights on the normative mechanisms of the state (e.g., Dobbin and Sutton 1998) with work on political strategy (Hillman et al. 2004). We discuss how this perspective is particularly relevant to emerging markets in which laws and regulations are frequently weak and enforcement is lacking (La Porta et al. 1998, Peng and Heath 1996, Young et al. 2008). We argue further that these insights are essential to developing a theory of political strategy that encompasses the diversity of corporate political mechanisms around the globe. Second, we show that different types of corporate political network ties (that is, ties to national congresses versus ties to the operating bureaucracy) affect firm behavior differently. Some political ties, such as executives serving on political councils, are more symbolic, resulting in correspondingly symbolic CSR action. Other ties, such as the extent of embeddedness in government bureaucracy, are more ongoing and concern material resources (Fan et al. 2007) and are therefore associated with greater monitoring and result in more substantial CSR action. Thus, the use of political networks can be a double-edged sword; they can increase access to resources but at the cost of more government monitoring. Finally, we contribute to institutional theory more specifically by introducing the idea that firms perceive a decoupling risk that leads to variations in symbolic strategies (Tilcsik 2010, Westphal and Zajac 2001) depending on the extent of external monitoring.

\section{China's Political Economy and CSR Reporting}

Since China introduced its open-door economic reform policy in 1978, the country has developed a unique hybrid market economy. Since the mid-1980s, many Chinese firms have been transformed from government entities to publicly traded state-owned enterprises (SOEs). The two Chinese stock exchanges, Shanghai and Shenzhen, were founded in the early 1990s, and by 2009 , they had over 1,600 listed firms. Table 1 provides details on the recent growth of publicly listed firms in China from 1999 to 2008, particularly SOEs and privately controlled firms.

Although SOEs have sold shares to outside investors, the government still maintains considerable ownership and control of these firms (Guthrie 2009). It holds significant sway over the economy and is a critical source of resources and legitimacy for firms (Naughton 2007). The central government and governments at other levels can still allocate such important business resources as licenses and permits, subsidies, and project approval (Li et al. 2008). However, a critical issue in such contexts is that the lack of a rule of law and the lack of government transparency can obscure the government's priorities and decision-making processes (He and Tian 2008, Young et al. 2008). Thus, as we argue below, firms face greater ambiguity in how to interact with the government. Responding appropriately to government signals becomes a critical way to build legitimacy with governmental actors (Marquis et al. 2011).

Chinese government priorities have been articulated in five-year plans since the founding of the People's Republic of China (PRC). These plans provide a statement of national economic development goals and lay out objectives for the subsequent five years (Naughton 2007). Many observers perceived an important shift in China's economic development in 2006, when the $\mathrm{Hu}$ Jintao administration announced the 11th Five-Year Plan for National Economic and Social Development, articulating a national vision based on the principles of a harmonious society and scientific development. This was widely viewed as a signal that the government was shifting from a policy of economic growth at all costs to one of economic growth balanced with the need to tackle pressing social and environmental problems (See 2009). That same year, the Sixth Plenum of the 16th Communist Party Committee (CPC) Central Committee stated that firms should "create a harmonious situation in which everyone promotes harmony, and focusing on enhancing a sense of social responsibility amongst citizens, enterprises and all kinds of organizations" (Sino-Swedish CSR Cooperation 2009).

In close succession, other governmental actors, including the Shanghai and Shenzhen stock exchanges and the State-owned Assets Supervision and Administration Commission, issued guidelines and recommendations on reporting corporate social and environmental activities as best practices for firms under their control (Lin 2010). Recently published in-depth case studies document the critical effect these steps had on CSR reporting practices in China (Marquis et al. 2010, 2011). For example, the first Chinese reference book providing practical guidance on preparing a CSR report was published in 2008 under the auspices of the Chinese Ministry of Commerce

Table 1 Publicly Listed Firms in China by Type of Control, 1999-2008

\begin{tabular}{lcccccccccc}
\hline & \multicolumn{10}{c}{ Year } \\
\cline { 2 - 10 } & 1999 & 2000 & 2001 & 2002 & 2003 & 2004 & 2005 & 2006 & 2007 & 2008 \\
\hline Number of listed firms & 930 & 1,088 & 1,140 & 1,204 & 1,258 & 1,355 & 1,351 & 1,434 & 1,529 & 1,592 \\
\% privately control & 16.88 & 18.59 & 18.42 & 22.59 & 26.55 & 30.85 & 30.79 & 35.29 & 38.78 & 39.57 \\
\% state owned & 83.12 & 81.41 & 81.58 & 77.41 & 73.45 & 69.15 & 69.21 & 64.71 & 61.22 & 60.43 \\
\hline
\end{tabular}


(Yin et al. 2008). In addition, the government developed its own reporting standard for Chinese companies (see, for example, Zhong 2009 for Chinese Academy of Social Sciences (CASS) standards 1.0 and 2.0). The bottom line, as noted by practitioners, is that whereas a Western company might "focus on its customers and investors as its most vital constituencies, the government sits at the top of the CSR pyramid in China as the important stakeholder in a business" (ChinaCSR.com 2009). Table A.1 in the appendix provides details of some of the critical communications the government has issued related to CSR and CSR reporting. ${ }^{1}$

Many observers have therefore concluded that (a) the government is sending signals through many channels that CSR is an appropriate and desired activity (Marquis et al. 2011, See 2009), and (b) Chinese firms have therefore stepped up the pace of their CSR activities, particularly reporting, since 2006 (China WTO Tribune 2009). Global firms have been introducing CSR reports since the 1990s, with over $80 \%$ of the largest firms worldwide issuing reports by 2005 (KPMG 2008), but large Chinese SOEs such as State Grid, the COSCO Group, China Mobile, and the Baosteel Group did not begin publishing annual sustainability or CSR reports until after these government signals began in 2006. In our database of approximately 1,600 Chinese publicly listed firms, 536 have issued at least one CSR report since then. Figure 2 shows the number of reports disclosed by Chinese publicly listed firms since 2006.

However, the quality of these reports varies significantly; in general, Chinese CSR reporting has been criticized for its low quality (China WTO Tribune 2009). For instance, half the reports released contained only limited information on specific CSR activities; only $7.8 \%$ of the reports referred to the Global Reporting Initiative's G3 (GRI 3.0) guidelines, the main international standard; and only $6.1 \%$ of the firms solicited third-party opinions of their reports (China WTO Tribune 2009). Thus, although Chinese firms may appear to be following government

\section{Figure 2 Number of CSR Reports Issued by Chinese} Publicly Listed Firms, 2006-2009

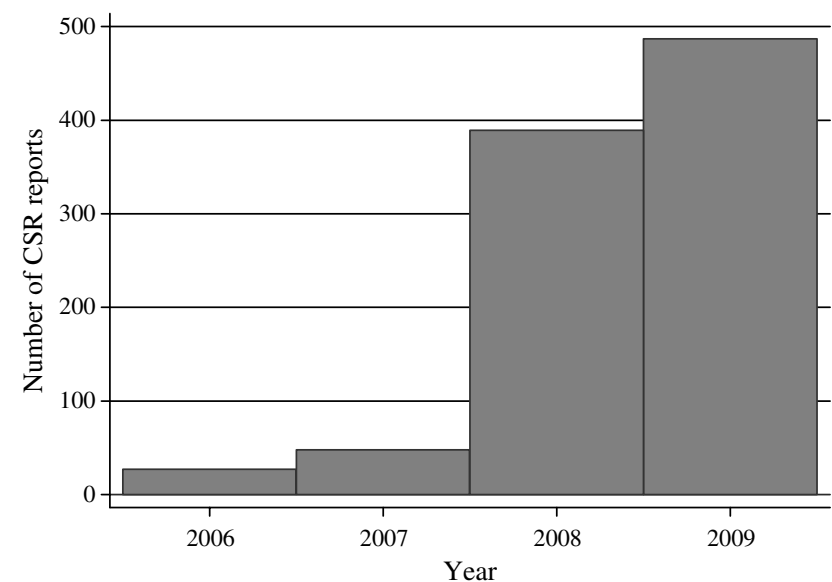

signals regarding CSR, it is clear that not all of them are doing so in a substantive way.

\section{CSR Reporting as a Political Strategy in China}

Governments control critical resources that shape firms' competitive environments and positions. As noted, political strategy research has focused on governmental activities such as regulation, subsidies, and taxation (Schuler and Rehbein 1997), showing that firms are strategic in managing their relationships with government entities so as to enhance their own positions (Hillman et al. 2004, Schuler et al. 2002). With political activities such as lobbying, political donations, and testimony, firms seek to reduce uncertainty, decrease transaction costs, and create business opportunities (Bonardi et al. 2006, Hillman et al. 1999, Lord 2000). Research on corporate political activities in the West has generally supported the notion that the greater the role of the government in a firm's immediate environment, the more likely the firm is to engage in political strategies (Baron 1995, Bonardi et al. 2005, Schuler and Rehbein 1997, Schuler et al. 2002). For example, in the United States, firms in industries represented by a congressional caucus are more likely to use lobbying and PAC contributions (Schuler et al. 2002).

Research has begun exploring how corporate political strategies may differ in emerging economies where there is typically a less developed legal and political infrastructure (e.g., Peng and Heath 1996). Thus far, this stream of research has mainly focused on the importance of firm leaders' personal network ties with the government (e.g., Li et al. 2006, Wang and Qian 2011). We expand the research to a broader context, observing that, on the one hand, government bodies are very strong and control many economic opportunities, including "industry access control, new investment ratification, value-added tax differentiation, control of pace and pattern of privatization or decentralization, and government involvement in business activities such as material sourcing, distribution, and marketing" (Luo 2003, p. 1319). On the other hand, because the rule of law is absent and there is, in general, an underdeveloped institutional infrastructure and weak enforcement of existing rules, it can be hard for firms to know how to interpret and respond to the government (He and Tian 2008, Marquis et al. 2011, Peng and Heath 1996). We argue that in such situations, responding to government signals and building legitimacy with governmental actors is critical.

The generality of this mechanism of responding to signals is supported by a deep stream of research in sociology that has studied how government action in the United States is as powerful in signaling norms and standards of legitimacy as it is in formally coercing compliance and has found that variations in how firms respond to the signals is driven by firm characteristics (Edelman and Suchman 1997). Regarding the strategic nature of 
such responses, Oliver and Holzinger (2008) pointed out that firms can comply with public policies or government regulations to derive as much value as possible, including legitimacy. In our study, political legitimacy is considered a strategic differentiator that firms pursue through multiple channels, depending on their specific situations. In China, state ownership of some firms allows us to more effectively distinguish the mechanisms of government control from the less direct influence of signaling legitimate action. Most researchers have focused on the cognitive and normative dimensions of legitimacy (Scott 2001), but the political bases of legitimacy need to be taken into account if one views legitimacy as a strategic corporate resource. Thus, although we focus on an important emerging economy research site to study this signaling mechanism, we also argue that this is a general political strategy that firms use worldwide, based on diverse research that has shown the importance of government signaling in developed economies as well.

In our empirical context, we view the Chinese government's statements and guidelines on CSR and CSR reporting since 2006 as akin to what Deephouse and Suchman (2008) refer to as legitimacy guidelinessignals sent by powerful actors that define appropriate activities for firms. Legitimacy guidelines from the government, however, provide a puzzle with respect to which organizations may be most likely to comply. Are organizations with high legitimacy (e.g., as a result of government ownership) more susceptible to these legitimacy guidelines, or does their status spare them from having to engage in further legitimacy building? Conversely, are firms with lower legitimacy (and hence more dependent on signaling) more likely to engage in legitimacy building in an effort to improve their positions?

Furthermore, as noted previously, the extent to which corporate relationships with the government create variations in monitoring will influence the extent and substance of CSR communications. Given stakeholder pressure to issue CSR reports, does a firm comply only symbolically (issuing vague, uninformative reports), or does it provide substantive details? Developing the idea of decoupling risk, we contend that organizations that are closely monitored by external stakeholders are more likely to engage in more substantive CSR.

\section{Governmental Actors and Political Legitimacy}

Our theoretical focus is on how the government influences corporate action by signaling norms and standards of legitimacy (Dobbin and Sutton 1998; Dobbin et al. 1993; Edelman 1990, 1992). We argue that acting in accordance with the government's communicated interests will afford a firm greater political legitimacy, which, in turn, gives the firm a greater positional advantage and less need to conform to government signals than firms with less political legitimacy.
In many economies, those both emerging and developed, there is significant government ownership, which is a key source of legitimacy and provides positional advantage (Faccio and Lang 2002, La Porta et al. 1999). This is the case in China, where the government not only is a key regulator and policymaker but also holds ownership stakes in many firms, both large and small. Sometimes it owns property rights; other times its influence is less direct. As state-owned ventures have been argued to "have legitimacy and receive support or even protection from the government agencies that have founded them" (Li and Zhang 2007, p. 794), we argue that SOEs have the most political legitimacy and therefore the least need to use activities such as CSR reporting to seek preferred status and associated resources from the government (Li and Zhang 2007, Ma and Parish 2006). As Brown (1998, p. 35, italics in original) noted, "Legitimate status is a sine qua non for easy access to resources, unrestricted access to markets, and long term survival." Firms lacking such positional advantage, such as privately controlled firms, may be more likely to view political legitimacy as a strategic need (Oliver and Holzinger 2008). Historically, because private owners and entrepreneurs in China had low social status and were even considered "enemies" of the people, they experienced discrimination that SOEs did not (Hong 2004, Huang 2008). Privately controlled firms, a relatively new organizational form in China, lack legitimacy in the economy and the society and therefore have stronger incentives to compensate by cultivating their relationships with the government (Li and Zhang 2007, Peng and Luo 2000).

Thus, although a simple control-oriented perspective would suggest that SOEs are the firms most likely to issue CSR reports as a result of coercive pressure from their government owners, such firms' inherent political legitimacy may instead buffer them from the need to communicate with government stakeholders. Our argument uncovers an irony in how different types of firms in China respond to government signals: the government articulates CSR reporting guidelines for all companies, yet our concept of political legitimacy suggests that such policies will mainly affect those that most need to enhance their legitimacy, the privately controlled firms. Indeed, previous research on Chinese firms has found that privately controlled firms exchange corporate donations for legitimacy and political access (Hong 2004, $\mathrm{Ma}$ and Parish 2006) and that they benefit more from their donations in terms of financial performance than do SOEs (Wang and Qian 2011). Similarly, by issuing CSR reports, privately controlled firms can create goodwill with government agencies and regulators and thus gain access to resources that are already easier for SOEs to obtain. We therefore hypothesize the following.

Hypothesis 1 (H1). Privately controlled firms are more likely than other types of firms to issue CSR reports. 


\section{Political Dependence and CSR Reports}

Although it is important to identify the relationship between government ownership and firm legitimacy, there are also less direct but no less important mechanisms of influence. We focus on three key factors that we believe either enhance or reduce a firm's political dependence and thus its need for political legitimacy; these are a firm's (1) political connections to influential government councils, (2) political legacy, and (3) financial resources. Our hypotheses articulate that these factors not only are important main effects but also modify the effect of private ownership on CSR reporting.

Connection to Political Councils. Government policy and enforcement constitute a major external source of uncertainty for firms and have been shown to be a critical influence on operations (Hillman et al. 1999, Pfeffer and Salancik 1978). Firms cultivate political connections to manage the dependencies that constrain their actions, thus decreasing risk and uncertainty and increasing access, information, legitimacy, and resources (Hillman 2005). A firm's political connections can be strategic assets (Hillman 2005, Siegel 2007), leading to preferential treatment by government-owned enterprises (such as banks or raw material producers), lighter taxation, preferential treatment in competition for government contracts, relaxed regulatory oversight of the company in question, or stiffer regulatory oversight of its rivals, and many other forms (Faccio 2006, p. 369). For instance, a study analyzing a sample of 450 politically connected firms from 35 countries between 1997 and 2002 found that politically connected firms were significantly more likely to be bailed out from economic distress than similar but poorly connected firms (Faccio et al. 2006).

In China, it is quite common for a firm's leadership to have political connections. The firm's executives may not only be members of the Chinese Communist Party but also hold top positions in the political system (Ma and Parish 2006). There are generally two types of political connections. First, corporate executives may be members of political councils such as the National People's Congress (NPC), the only legislative body in China, or the Chinese People's Political Consultative Conference (CPPCC), an advisory board for the Chinese government. Second, corporate executives may themselves be government officials, for example, bureaucrats in government agencies. Research has suggested that the former may have greater symbolic benefit (O'Brien 1990) and the latter greater material benefit ( $\mathrm{Li}$ and Zhang 2007, Peng and Luo 2000). The distinct functions of these two types of political connections have significant implications for a firm's political dependence and its risk of monitoring by the government. In this section, we consider the symbolic benefit of a firm's executives serving on national political councils and how this would affect CSR reporting. In a subsequent section, we focus on how a firm's bureaucratic embeddedness affects the substantiveness of its CSR reporting.

The NPC and CPPCC are often collectively referred as the "Two Meetings," signifying their status as the two most important political councils in China and the key means for business leaders to participate in the government. Each council meets once a year and serves as a forum for mediating policy differences between the Chinese Communist Party and various parts of Chinese society. Research has suggested that a three- to five-year membership in either of the councils does more to signal social prestige than to deliver any immediate business benefit (O'Brien 1990). The influence of these bodies on the operating government is quite low, as the Communist Party and the government still maintain very strong influence and power over the legislature ( $\mathrm{Li}$ et al. 2006). For instance, NPC representatives are welcome to make suggestions to the government but are forbidden to intervene in legislative and judicial activities (O'Brien 1990). The CPPCC is even more symbolic as its only function is advisory; it has no right to participate in the creation of policies and regulations (Ma and Parish 2006, Saich 2001).

In the context of CSR reporting, we contend that political network connections created by corporate executives serving on these councils are more likely to lead to firms responding to government pressure for CSR reporting to sustain their reputations. By taking action in accordance with government policies, positions, and regulationsfor example, by issuing CSR reports-firms and their executives maintain their legitimacy in the eyes of the government. Moreover, it can be harder for executives in privately controlled firms to become members of these political councils than it is for executives in SOEs, so the value of that membership is higher for them. Thus the impact of these connections on issuing CSR reports may be particularly important for privately controlled firms, as responding to policy signals may be one of the few ways they can show their commitment to government initiatives. We therefore hypothesize that these connections also reinforce the previously hypothesized effect of private control.

Hypothesis 2A (H2A). Firms whose chief executive officers (CEOs) are members of national political councils are more likely to issue CSR reports.

HYPOTHESIS 2B (H2B). The effect of private control on a firm's CSR reporting will be stronger for firms whose CEOs are members of national political councils.

Political Legacy. Another key organizational characteristic is how a firm's founding era creates internal institutions and connections that result in persistent commitment to the political system of that era. Research has theorized that stakeholder relationships are 
path-dependent (Barnett 2007) and has shown that government influence at a firm's founding imprints the firm in such a way that its subsequent actions reflect the initial state policy (Marquis and Tilcsik 2013, Stinchcombe 1965). A growing stream of research on how being founded in a socialist political environment affects a firm's subsequent strategies (Kogut and Zander 2000, Kriauciunas and Kale 2006) describes such "socialist imprinting" as a process whereby firm-specific capabilities and knowledge resources are also era-specific. After market transitions, such capabilities prove to be ill-suited to the new environment.

Chinese reform has tended toward gradual market liberalization over the past 30 years, but the change has accelerated recently. For instance, direct government intervention in business has been reduced since the implementation of the 2004 PRC Administrative Approval Law, which provides guidelines for government activities and protects the interests of Chinese citizens, legal persons, and other interest groups. Thus, it is likely that older firms have a greater "socialist imprint" than younger firms and are less likely to pursue recent trends and management ideas that are inconsistent with their operating ideologies. Indeed, studies have found that older Chinese firms have well established structures and vested interests and are less likely to respond to new governance practices such as the appointment of outside directors; younger firms, by contrast, have stronger incentives to establish their legitimacy and thus to introduce new governance practices (Peng 2004). Firms founded when state control of the economy was more extensive are probably not as attuned to new globally diffused practices such as CSR reporting and do not feel as much legitimacy pressure to adopt them.

It would also follow that the effect of private control on the pursuit of political legitimacy by issuing CSR reports would be weaker for older privately controlled firms than for younger firms. These older firms, being imprinted with legitimacy-seeking strategies prevalent in the socialist era, would have more difficulty adopting the newer practices. These arguments lead us to offer the following hypotheses.

Hypothesis 3A (H3A). Older firms are less likely to issue CSR reports.

HYPOTHESIS 3B (H3B). The effect of private control on CSR reporting will be weaker for older firms.

Financial Resources. Research has shown that firms with greater financial resources are more able to engage in political activities (Schuler and Rehbein 1997) and capture a larger portion of the associated benefits (Hillman et al. 2004) and that slack resources significantly affect corporate social activities such as philanthropy (Seifert et al. 2004, Waddock and Graves 1997, Wang et al. 2008). Research has also found that organizations are more likely to follow legitimated practices to a greater extent if they have greater financial resources (Park et al. 2011). If the purpose of CSR and CSR reporting is to gain legitimacy from the government, then both higher-performing firms and those with more slack resources would be more likely to mobilize those resources to issue CSR reports.

Compared with SOEs, which typically benefit from government backing and resources, privately controlled firms' actions are in general more responsive to changes in their financial positions. Therefore, we expect a privately controlled firm's CSR reporting to be particularly responsive to its financial resources and, in particular, expect that greater financial resources would increase the likelihood of CSR reporting. Moreover, greater financial resources may create higher external pressure for these firms to be more transparent and engage in more CSRrelated activities.

Hypothesis 4A (H4A). Firms with greater financial resources (higher performance and more slack) are more likely to issue CSR reports.

HyPOTHESIS 4B (H4B). The effect of private control on CSR reporting will be enhanced for firms with greater financial resources (higher performance and more slack).

\section{Government Monitoring and Substantive CSR Reporting}

A firm's response to its dependence on the government may vary with the likelihood or extent of government monitoring. One common response is decoupling (Meyer and Rowan 1977) - the symbolic compliance with a stakeholder demand without making substantive changes. For example, a series of studies by Westphal and Zajac $(1994,1995,2001)$ have shown that firms often respond to stakeholder demands, such as to issue stock buybacks and create executive incentive programs, by publicizing actions that they have not actually taken. In another domain, governments may put pressure on schools to adopt certain standards or curricula, with little effect on actual teaching processes (Meyer and Rowan 1978). Decoupling is a useful strategy for firms because it "enables organizations to maintain standardized, legitimating, formal structures, while their activities vary in response to practical considerations" (Meyer and Rowan 1977, p. 357).

Most research on decoupling suggests that because stakeholders typically do not scrutinize implementation (Zajac and Westphal 2004), there has been little consideration of what would happen if decoupling were exposed. However, research on greenwashing, a strategy similar to decoupling whereby firms overemphasize positive aspects of their environmental records to mask their actual performance, suggests that there are significant risks to this strategy in that stakeholders punish firms 
exposed as greenwashers, even if their environmental performance is better than organizations that do not greenwash. In one notable case, British Petroleum, having touted itself as "Beyond Petroleum," received more criticism for its environmental record than did Exxon, a firm generally considered to have a worse environmental impact (Lyon and Maxwell 2011). This suggests that a firm's information disclosure is sometimes monitored and that there is a risk of censure if that firm is found to have engaged in obfuscation or symbolic compliance rather than having done what it claimed. This perspective is also consistent with Campbell's (2007) proposition that firms are more likely to act in socially responsible ways when actors such as non-governmental organizations, social movements, and media monitor their behavior. For example, studies have shown that government oversight or monitoring leads to higher rates of implementation of labor provisions (Dobbin et al. 2009), environmental self-regulation (Short and Toffel 2010), and corporate governance codes that are easier to monitor (Okhmatovskiy and David 2012).

We depart from the traditional decoupling perspective that suggests implementation is not scrutinized (Zajac and Westphal 2004), focusing instead on what we term decoupling risk: how the risk that a firm's decoupling will be exposed varies across firms. We expect firms with higher decoupling risk (i.e., those whose activities are more likely to be monitored) to be more likely to engage in substantive CSR reporting. (As mentioned earlier, the high variation in the details of CSR reports allows us to determine the extent to which those reports indicate actual CSR activities. ${ }^{2}$ ) We hypothesize how increased monitoring-and therefore increased likelihood of substantial CSR activity-can emerge from two types of government relation: bureaucratic embeddedness and regional government institutional development.

Bureaucratic Embeddedness. As discussed above, government connections are an important strategy by which Chinese firms gain access to resources. A firm can gain great symbolic benefit if its executives attend the annual meetings of large national congresses such as the NPC and CPPCC. However, there are other types of government connections that are more ongoing and that may expose the firm to more stringent monitoring. In China, executives can hold government positions; for example, they can be heads of governmental departments and bureaus (Fan et al. 2007). Such bureaucratic connections have been shown to confer greater access to resources or material benefit than do the more symbolic connections to national congresses. For instance, Peng and Luo (2000) found that managers' interpersonal ties with government officials helped improve their firms' performance. Li and Zhang (2007) also found that new ventures in China rely on government officials to obtain information and funding that contribute to performance. Furthermore, firms with such political connections often have better access to resources critical for growth (Nee 1992).

Yet, for a number of reasons, such bureaucratic embeddedness is also likely to expose a firm to greater government monitoring. First, research has shown that government agencies and bureaucracies are the key government areas responsible for policy implementation. This leads to greater organizational oversight (Bonardi et al. 2006, Hiatt and Park 2013). Second, such connections are more ongoing and involve closer connections with the government. For instance, Dickson (2003) argued that including top business leaders in the bureaucracy is a means of co-opting them, giving the government another form of informal control over the economy. Existing CEOs can be recruited into the government. Furthermore, the Chinese government may appoint or encourage government officials to become executives or directors of firms in order to gain more control over those firms (Fan et al. 2007). Whereas firms may create or maintain bureaucratic ties for increased access to resources, these ties are also likely to subject the firm to greater scrutiny, in turn making the firm more likely to engage in substantial CSR practices (Dickson 2003). We therefore hypothesize the following.

HYPOTHESIs 5. Firms whose leaders hold positions as government officials will be more likely to engage in more substantive CSR reporting.

Regional Government Institutional Development. Prior research on the relationship between a firm's institutional environment and the political strategies it adopts in response has typically emphasized the importance of institutional differences at the federal or central levels (Hillman et al. 2004), with limited attention to how variations within a country affects firms' political strategies.

Yet the latter perspective is particularly important in emerging economies such as China, where the undeveloped institutional infrastructure creates challenges for firms (Young et al. 2008). During the reform period, there have been significant variations across China in the extent to which regional governments have seized the opportunity to use market mechanisms to develop the local economy, enhance fiscal health, and, correspondingly, enhance development of regional government institutions. The fiscal reforms of the 1980s gave certain economic rights and responsibilities to each government jurisdiction above the village level, thus increasing local and provincial government revenues (Walder 1995). ${ }^{3}$ As a result, governments in developed regions have accumulated significant financial resources and have introduced more advanced management techniques, making them more likely to have not only the resources but also the expertise to monitor corporate activities (Brandt and Li 2003, Goldstein 1995). We therefore hypothesize the following. 
HYPOTHESIS 6. Firms headquartered in more institutionally developed regions will be more likely to engage in more substantive CSR reporting.

\section{Methods and Analyses}

\section{Data and Sample}

This study covers all Chinese firms that were listed on the Shanghai or Shenzhen stock exchanges from 2006 to 2009. Data sources include archival data from the China Stock Market and Accounting Research (CSMAR) database, firms' annual reports and CSR reports, the National Bureau of Statistics of China, and CSR report ratings from the CSR rating agency Runling (also known by its English acronym, RKS; http://www.rksratings.com). CSMAR is the primary source for information on Chinese stock markets and the financial statements of Chinese listed firms. Corporate annual reports provide a biographical sketch of the CEO, including his or her previous experience in industry and government (Fan et al. 2007). CSR reports were also downloaded from firm and stock exchange websites. Our ratings of the substance of a firm's CSR report are from RKS and cover 2008 and 2009. We complement that information with provincial-level development data from the Chinese Statistics Bureau. After merging these databases and removing observations that were missing key explanatory variables (about 6\%), we have a sample of 5,660 firm-year observations. There is a one-year lag between all independent and dependent variables.

\section{Measures}

Dependent Variables. Our main foci in this study are the factors that would affect (a) whether a firm issues a CSR report and (b) the substance of CSR activities depicted in the report. Thus, we have two dependent variables. CSR report is a dummy variable equal to 1 if the focal firm has issued a CSR report in a given year, and it is 0 otherwise. In our sample, the number of CSR reports issued by Chinese public firms increased year after year (see Figure 2).

CSR reporting substantiveness is an overall rating of CSR activities as portrayed in the report. We obtained these ratings from the RKS, whose organization and China-specific products are modeled after the U.S. social investment rating agency Kinder, Lydenberg, Domini \& Co., Inc. (KLD). Like KLD, RKS is entirely independent of the companies it rates. Because what it rates is firms' activities as presented in their CSR reports, the data it gathers are from those reports as well as other firm communications such as websites and press releases. Firms' CSR activities are rated along three dimensions: (1) overall evaluation includes a firm's CSR strategy, the extent of stakeholder participation in CSR activities, the comparability of report information over time, the innovativeness of the firm's CSR activities, and the extent of external auditing; (2) content evaluation focuses on the extent of leadership and organizational systems in place for implementing CSR and on specific metrics for economic, environmental, and social responsibilities; and (3) technical evaluation focuses on items such as the transparency, regularity, and availability of CSR information. These three dimensions together include over 70 subdimensions (the list is available from the authors). The rating ranges from 0 to 100 . This evaluation system is based on the GRI 3.0 guidelines, which RKS adapted for use in China by adding China-specific CSR elements. For example, Chinese firms frequently publicize the amount of taxes they pay to the government as a form of social responsibility, which RKS captures. Each CSR report is evaluated by at least three RKS experts, each with at least three years of CSR experience and no conflicts of interests involving the focal firm.

Given our interest in assessing the extent to which CSR reporting reflects a greater degree of substantive CSR activity, an alternative to the RKS composite measure (all three dimensions) would be to take into account only the overall evaluation and content evaluation dimensions. We conducted supplementary analyses with this alternative dependent variable as well as a number of other robustness checks ${ }^{4}$ and always achieved the same results (results available from the authors on request).

Independent Variables. Two sets of independent variables were used to test the hypotheses predicting the two dependent variables. For the analysis of the CSR report, we used the following independent variables: private control is a dummy variable equal to 1 if the firm was owned by dispersed private shareholders and 0 if the ultimate owner was the Chinese government and its agencies (Wang et al. 2008). ${ }^{5}$ CEO NPC/CPPCC membership is a dummy variable equal to 1 if the CEO was a member of the CPCC, and 0 otherwise. ${ }^{6}$

Firm age is the number of years since the firm was established. Financial resources were captured by two variables: firm ROA is the return on assets calculated as net income over total assets, a common accountingbased measure of financial performance. ROA is seen as the best performance measure to use in China (Peng and Luo 2000). Seifert et al. (2004) argued that cash flow better captures the notion of available resources for discretionary purposes. Thus, we calculated slack resources as the sum of cash flow from a firm's operating, financing, and investing activities. To control for firm size, we scaled slack resources by total assets (Carow et al. 2004).

For the analysis of CSR reporting substantiveness, we used the following independent variables: $C E O$ as government official is a dummy variable used to measure bureaucratic embeddedness. It equals 1 when the CEO is or has been an officer of the central or regional governments, and it is 0 otherwise (Bai et al. 2006, Li et al. 2006). As noted, we expect that firms in regions of 
China with more developed governments will issue more substantive CSR reports. We measure regional institutional development as a province's gross domestic product (GDP) per capita (i.e., the province's GDP divided by its population), which we obtained from the Chinese Statistics Bureau. This is consistent with prior research showing that economic development is highly related to government development in China (Walder 1995).

Control Variables. We controlled for additional variables that may affect either a firm's decision to issue a CSR report or the report's substantiveness.

Because larger firms may have more staff and infrastructure with which to issue CSR reports or to provide greater substance, we include firm size, the natural log of a firm's total assets.

Stock market regulations require some firms to produce CSR reports. For instance, in May 2008, the Shanghai Stock Exchange issued a policy requiring firms in the corporate governance group ${ }^{7}$ firms listed on foreign stock exchanges such as New York Stock Exchange (NYSE) and Hong Kong Stock Exchange (HKSE), and firms in financial industries to issue CSR reports. In the Shenzhen Stock Exchange, firms belonging to the SZSE 100 Index are required to issue CSR reports. We therefore include required discloser, a dummy variable equal to 1 if a firm's characteristics suggest it would be required to issue a CSR report in a given year and 0 otherwise. $^{8}$

We expect that highly visible firms will be more likely to disclose CSR reports and that their reports will be more substantive. We chose five newspapersPeople's Daily, the International Finance News, the Market News, the Jinghua News, and the Jiangnan News-for their prevalence in and relevance to firm economic activities. We used a website search engine (http://www.search.people.com.cn) to assign a value to media exposure, the number of news articles about a focal firm in a given year.

Because firms with experience issuing CSR reports may be more likely to do so in a given year and to do so more substantively, we also controlled for reporting experience, which is equal to 1 if the focal firm has issued a CSR report before and 0 otherwise. ${ }^{9}$

To the extent that Chinese firms are becoming global, they may be exposed to additional pressures regarding reporting and transparency (KPMG 2008). We therefore controlled for foreign sales and international exposure as measures of the pressure a firm faces from the international market. Foreign sales is the firm's foreign sales as a percentage of total sales (Hitt et al. 1997). International stockholders is a dummy variable equal to 1 if a firm is cross-listed in international stock market exchanges such as HKSE and NYSE or has issued $\mathrm{B}$-shares to foreign investors. These two variables are important to control for the extent to which international pressure drives a firm's CSR reporting.
Because there could be a difference between firms listed in the Shenzhen and Shanghai stock exchanges, we included a dummy variable, stock market exchange, which is equal to 1 if the firm is listed on the Shenzhen Stock Exchange and 0 if it is listed on the Shanghai Stock Exchange.

There is a significant variation in the extent of CSR reporting across the years of our study (2006-2009). To control for a potential time effect, we included year dummy variables in the analysis. Furthermore, to control for possible differences in CSR reporting across industries, which may be under pressure from different sources, we included 12 industry dummies representing the 13 industry categories ${ }^{10}$ identified by the China Securities Regulatory Commission. ${ }^{11}$

Predictors of CSR Reporting Substantiveness. To control for the fact that stakeholder monitoring might affect the probability of issuing a CSR report, we also included the key predictors of CSR reporting substantiveness, CEO as government official and regional institutional development, as control variables when predicting the probability of a CSR report.

\section{Estimation Method}

We used a different method to test each of our two predictions. ${ }^{12}$ The first analysis involved estimating the probability of a firm issuing a CSR report by applying a logit model to the entire sample of 5,660 firm-year observations. We then used ordinary least squares (OLS) regression to examine the relationship between monitoring and substantive CSR reporting. The sample was limited to firms whose CSR reports had been rated by RKS, which resulted in 791 observations. ${ }^{13}$ To control for multiple observations per firm and for any potential heteroskedasticity, we report cluster-adjusted and heteroskedasticity-robust standard errors in both our analyses. We conducted our statistical analysis using Stata 11.1.

\section{Results}

Table 2 presents the descriptive statistics and correlations for each of our variables. Panel A includes the variables used in the logit model to predict the probability of a firm issuing a CSR report; panel B includes the variables used in the OLS regression to predict the substantiveness of CSR reporting. Because in this analysis there are significant intercorrelations among some variables, we computed variance inflation factors (VIFs) to investigate whether there was a potential multicollinearity problem. The maximum VIF obtained in any of the models was 2.4 (firm size); the mean VIF was 1.3, below the ruleof-thumb cutoff of 10 (Ryan 1997). Therefore, we do not believe that multicollinearity significantly affects our results. 


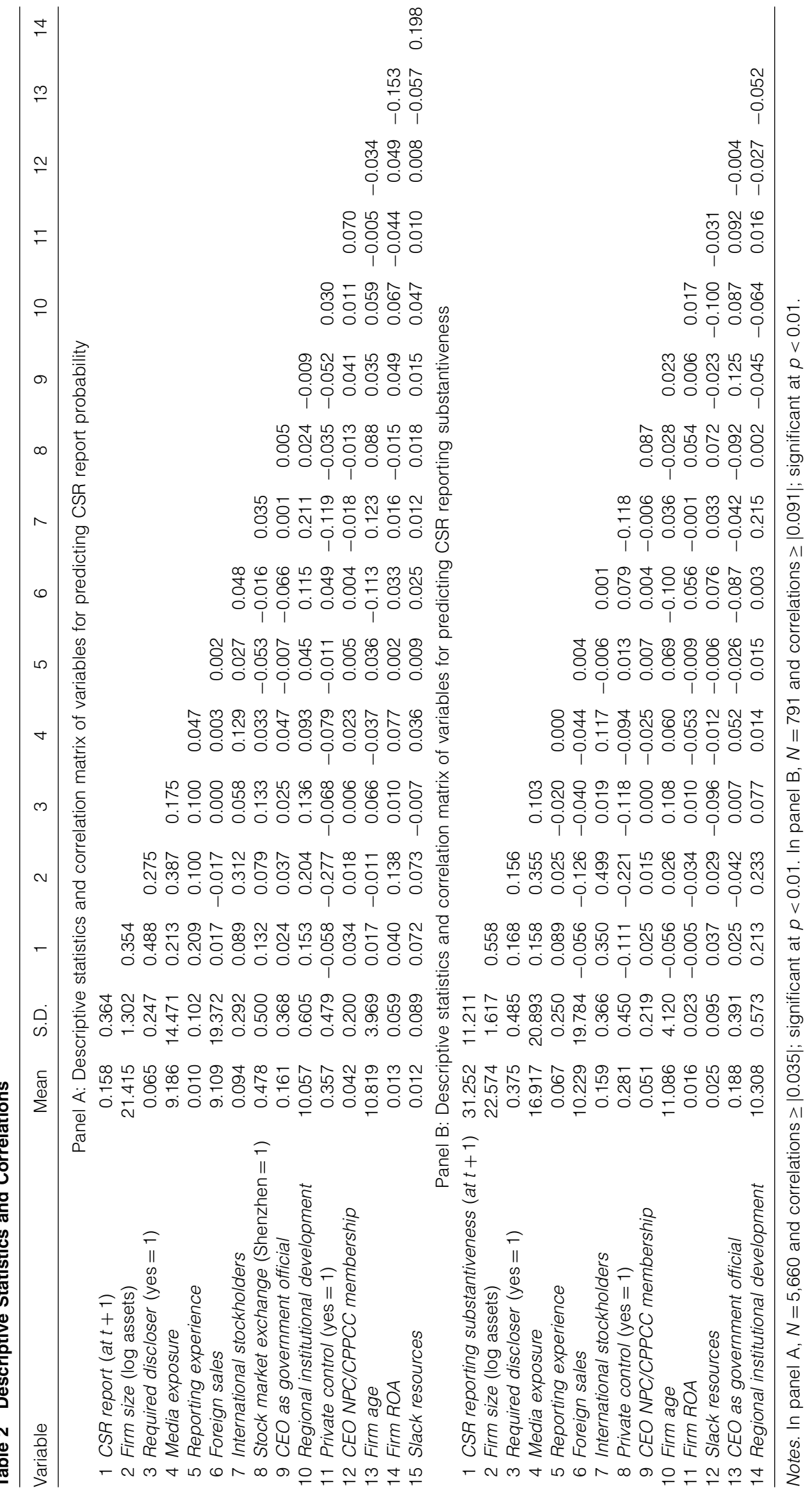


Table 3 Estimates from Logistic Regression of Firm CSR Report Probability (CSR Report=1), 2006-2009

\begin{tabular}{|c|c|c|c|c|c|c|c|}
\hline Variable & Model 1 & Model 2 & Model 3 & Model 4 & Model 5 & Model 6 & Model 7 \\
\hline \multicolumn{8}{|l|}{ Organizational and environmental controls } \\
\hline Firm size & $\begin{array}{l}0.533^{* * *} \\
(0.055)\end{array}$ & $\begin{array}{l}0.542^{* * *} \\
(0.056)\end{array}$ & $\begin{array}{l}0.530^{* * *} \\
(0.057)\end{array}$ & $\begin{array}{l}0.531^{* * *} \\
(0.057)\end{array}$ & $\begin{array}{l}0.541^{* * *} \\
(0.057)\end{array}$ & $\begin{array}{l}0.539 * * * \\
(0.058)\end{array}$ & $\begin{array}{l}0.548^{* * *} \\
(0.058)\end{array}$ \\
\hline Required discloser (yes $=1$ ) & $\begin{array}{l}2.859^{* * * *} \\
(0.178)\end{array}$ & $\begin{array}{l}2.863^{* * *} \\
(0.178)\end{array}$ & $\begin{array}{l}2.844^{* * *} \\
(0.178)\end{array}$ & $\begin{array}{l}2.845^{* * * *} \\
(0.178)\end{array}$ & $\begin{array}{l}2.846^{* * *} \\
(0.179)\end{array}$ & $\begin{array}{l}2.832^{* * *} \\
(0.178)\end{array}$ & $\begin{array}{l}2.835^{* * *} \\
(0.179)\end{array}$ \\
\hline Media exposure & $\begin{array}{l}0.013^{* * *} \\
(0.004)\end{array}$ & $\begin{array}{l}0.013^{* * *} \\
(0.004)\end{array}$ & $\begin{array}{l}0.012^{* * *} \\
(0.004)\end{array}$ & $\begin{array}{l}0.012^{* * *} \\
(0.004)\end{array}$ & $\begin{array}{l}0.012^{* * *} \\
(0.004)\end{array}$ & $\begin{array}{l}0.012^{* * *} \\
(0.004)\end{array}$ & $\begin{array}{l}0.012^{* * *} \\
(0.004)\end{array}$ \\
\hline Reporting experience & $\begin{array}{l}3.711^{* * *} \\
(0.660)\end{array}$ & $\begin{array}{l}3.704^{* * *} \\
(0.660)\end{array}$ & $\begin{array}{l}3.686^{* * *} \\
(0.658)\end{array}$ & $\begin{array}{l}3.688^{* * *} \\
(0.658)\end{array}$ & $\begin{array}{l}3.666^{* * *} \\
(0.664)\end{array}$ & $\begin{array}{l}3.701^{* * *} \\
(0.658)\end{array}$ & $\begin{array}{l}3.679 * * * \\
(0.662)\end{array}$ \\
\hline Foreign sales & $\begin{array}{c}0.005^{+} \\
(0.003)\end{array}$ & $\begin{array}{c}0.005^{+} \\
(0.003)\end{array}$ & $\begin{array}{c}0.004 \\
(0.003)\end{array}$ & $\begin{array}{c}0.004 \\
(0.003)\end{array}$ & $\begin{array}{c}0.004 \\
(0.003)\end{array}$ & $\begin{array}{c}0.004 \\
(0.003)\end{array}$ & $\begin{array}{c}0.004 \\
(0.003)\end{array}$ \\
\hline International stockholders & $\begin{array}{c}-0.326 \\
(0.201)\end{array}$ & $\begin{array}{c}-0.319 \\
(0.202)\end{array}$ & $\begin{array}{c}-0.219 \\
(0.202)\end{array}$ & $\begin{array}{c}-0.221 \\
(0.202)\end{array}$ & $\begin{array}{c}-0.235 \\
(0.202)\end{array}$ & $\begin{array}{c}-0.229 \\
(0.203)\end{array}$ & $\begin{array}{c}-0.244 \\
(0.203)\end{array}$ \\
\hline Stock market exchange $($ Shenzhen $=1)$ & $\begin{array}{r}0.233^{*} \\
(0.114)\end{array}$ & $\begin{array}{r}0.241^{*} \\
(0.114)\end{array}$ & $\begin{array}{r}0.282^{*} \\
(0.115)\end{array}$ & $\begin{array}{r}0.282^{*} \\
(0.115)\end{array}$ & $\begin{array}{l}0.304^{* *} \\
(0.115)\end{array}$ & $\begin{array}{r}0.282^{*} \\
(0.115)\end{array}$ & $\begin{array}{l}0.301^{* *} \\
(0.115)\end{array}$ \\
\hline CEO as government official & $\begin{array}{l}0.117 \\
(0.157)\end{array}$ & $\begin{array}{l}0.121 \\
(0.158)\end{array}$ & $\begin{array}{l}0.076 \\
(0.157)\end{array}$ & $\begin{array}{c}0.079 \\
(0.157)\end{array}$ & $\begin{array}{l}0.074 \\
(0.157)\end{array}$ & $\begin{array}{c}0.072 \\
(0.157)\end{array}$ & $\begin{array}{c}0.073 \\
(0.157)\end{array}$ \\
\hline Regional development & $\begin{array}{l}0.037 \\
(0.107)\end{array}$ & $\begin{array}{l}0.031 \\
(0.108)\end{array}$ & $\begin{array}{c}-0.004 \\
(0.107)\end{array}$ & $\begin{array}{r}-0.003 \\
(0.107)\end{array}$ & $\begin{array}{c}-0.025 \\
(0.110)\end{array}$ & $\begin{array}{r}-0.008 \\
(0.108)\end{array}$ & $\begin{array}{r}-0.024 \\
(0.109)\end{array}$ \\
\hline \multicolumn{8}{|c|}{ Sociopolitical legitimacy and dependence controls } \\
\hline $\mathrm{H} 1$ : Private control $($ yes $=1)$ & & $\begin{array}{l}0.098 \\
(0.132)\end{array}$ & $\begin{array}{c}0.021 \\
(0.133)\end{array}$ & $\begin{array}{l}0.005 \\
(0.138)\end{array}$ & $\begin{array}{r}0.666^{+} \\
(0.354)\end{array}$ & $\begin{array}{r}-0.090 \\
(0.145)\end{array}$ & $\begin{array}{l}0.465 \\
(0.364)\end{array}$ \\
\hline H2A: CEO NPC/CPPCC membership & & & $\begin{array}{r}0.506^{*} \\
(0.259)\end{array}$ & $\begin{array}{c}0.362 \\
(0.367)\end{array}$ & $\begin{array}{r}0.517^{*} \\
(0.258)\end{array}$ & $\begin{array}{r}0.503^{*} \\
(0.258)\end{array}$ & $\begin{array}{l}0.385 \\
(0.368)\end{array}$ \\
\hline H3A: Firm age & & & $\begin{array}{r}-0.037^{*} \\
(0.016)\end{array}$ & $\begin{array}{r}-0.038^{*} \\
(0.016)\end{array}$ & $\begin{array}{c}-0.013 \\
(0.021)\end{array}$ & $\begin{array}{r}-0.036^{*} \\
(0.016)\end{array}$ & $\begin{array}{l}-0.016 \\
(0.021)\end{array}$ \\
\hline H4A: Firm ROA & & & $\begin{array}{l}9.328^{* * *} \\
(1.592)\end{array}$ & $\begin{array}{l}9.333^{* * *} \\
(1.594)\end{array}$ & $\begin{array}{l}9.565^{* * *} \\
(1.632)\end{array}$ & $\begin{array}{l}8.468^{* * *} \\
(1.984)\end{array}$ & $\begin{array}{l}8.824^{* * *} \\
(2.029)\end{array}$ \\
\hline H4A: Slack resources & & & $\begin{array}{l}1.168^{*} \\
(0.496)\end{array}$ & $\begin{array}{l}1.163^{*} \\
(0.497)\end{array}$ & $\begin{aligned} 1.081^{*} \\
(0.489)\end{aligned}$ & $\begin{array}{l}0.099 \\
(0.691)\end{array}$ & $\begin{array}{c}0.129 \\
(0.699)\end{array}$ \\
\hline $\begin{array}{l}\text { H2B: Private controlx } \\
\quad \text { CEO NPC/CPPCC membership }\end{array}$ & & & & $\begin{array}{l}0.263 \\
(0.512)\end{array}$ & & & $\begin{array}{c}0.229 \\
(0.551)\end{array}$ \\
\hline H3B: Private control $\times$ Firm age & & & & & $\begin{array}{r}-0.059^{*} \\
(0.031)\end{array}$ & & $\begin{array}{r}-0.051^{+} \\
(0.031)\end{array}$ \\
\hline $\mathrm{H} 4 \mathrm{~B}$ : Private control $\times \mathrm{ROA}$ & & & & & & $\begin{array}{l}2.451 \\
(2.843)\end{array}$ & $\begin{array}{l}2.054 \\
(2.849)\end{array}$ \\
\hline H4B: Private control $\times$ Slack resources & & & & & & $\begin{array}{l}2.234^{*} \\
(0.975)\end{array}$ & $\begin{array}{r}1.971^{*} \\
(0.965)\end{array}$ \\
\hline Constant & $\begin{array}{l}-14.117^{* * *} \\
(1.591)\end{array}$ & $\begin{array}{l}-14.315^{* * *} \\
(1.611)\end{array}$ & $\begin{array}{l}-13.152^{* * *} \\
(1.165)\end{array}$ & $\begin{array}{l}-13.176^{* * *} \\
\quad(1.644)\end{array}$ & $\begin{array}{l}-13.432^{* * *} \\
(1.657)\end{array}$ & $\begin{array}{l}-13.253^{* * *} \\
(1.655)\end{array}$ & $\begin{array}{l}-13.502^{* * *} \\
\quad(1.661)\end{array}$ \\
\hline $\begin{array}{l}\text { No. of observations } \\
\text { Pseudo } R^{2}\end{array}$ & $\begin{array}{l}5,660 \\
0.387\end{array}$ & $\begin{array}{l}5,660 \\
0.387\end{array}$ & $\begin{array}{l}5,660 \\
0.399\end{array}$ & $\begin{array}{l}5,660 \\
0.399\end{array}$ & $\begin{array}{l}5,660 \\
0.400\end{array}$ & $\begin{array}{l}5,660 \\
0.401\end{array}$ & $\begin{array}{l}5,660 \\
0.401\end{array}$ \\
\hline Log pseudo-likelihood & $-1,512.82$ & $-1,512.41$ & $-1,482.35$ & $-1,482.17$ & $-1,479.63$ & $-1,479.38$ & $-1,477.25$ \\
\hline Wald $\chi^{2}$ & $\begin{array}{c}726.50 \\
(24)^{* * *}\end{array}$ & $\begin{array}{c}735.94 \\
(25)^{* * *}\end{array}$ & $\begin{array}{l}701.00 \\
(29)^{* * * *}\end{array}$ & $\begin{array}{l}701.46 \\
(30)^{* * * *}\end{array}$ & $\begin{array}{l}698.57 \\
(30)^{* * * *}\end{array}$ & $\begin{array}{c}700.64 \\
(31)^{* * *}\end{array}$ & $\begin{array}{l}699.77 \\
(33)^{* * *}\end{array}$ \\
\hline
\end{tabular}

Note. Robust standard errors are in parentheses; year and industry dummies are included but not reported here. ${ }^{+} p<0.10 ;{ }^{*} p<0.05 ;{ }^{* *} p<0.01 ;{ }^{* * *} p<0.001$ (two-tailed test).

Table 3 presents the logistic regression estimates of the probability of a firm issuing a CSR report. Model 1 included all the organizational and environmental control variables. Firm size, required discloser, reporting experience, media exposure, and stock market exchange all had significant influence on the probability of issuing a CSR report.

Models 2-7 tested the hypotheses. In Model 2, the coefficient of private control was positive as predicted but below marginal significance. Hypothesis 1 was therefore not supported. Hypotheses $2 \mathrm{~A}$ and $2 \mathrm{~B}$ stated that firms whose CEOs are members of national political councils would be more likely to issue CSR reports and that this would strengthen the effect of private control on CSR reporting. In Model 3, the main effect of CEOs as political council members was positive and significant, supporting Hypothesis 2A. When holding other variables at their mean, the probability of issuing a CSR report is $3.49 \%$ higher for firms with CEOs who are members of the NPC or CPPCC than the probability for firms without such connections. However, in Model 4, the interaction term between CEO NPC/CPPCC membership and 
private control was not significant; Hypothesis $2 \mathrm{~B}$ therefore was not supported.

Hypotheses $3 \mathrm{~A}$ and $3 \mathrm{~B}$ predicted that older firms are less likely to issue CSR reports and that the positive impact of private control will be weakened for older firms. In Model 3, firm age was negatively related to the probability of CSR reporting $(p<0.01)$, supporting Hypothesis 3A. A one-standard-deviation increase in firm age decreases the probability of issuing a CSR report by $8.1 \%$. In Model 5, firm age negatively interacted with private control $(p<0.05)$, lending support to Hypothesis 3B.

Hypotheses 4A and 4B predicted that a firm's financial resources, measured as firm ROA and slack resources, would positively affect the probability of CSR reporting and would also moderate the impact of private control on the probability of CSR reporting. In Model 3, both firm ROA and slack resources positively affected CSR reporting (at $p<0.001$ and $p<0.05$, respectively), providing support for Hypothesis 4A. A one-standard-deviation increase in firm ROA increases the probability of issuing a CSR report by $8.41 \%$ (from $6.18 \%$ to $14.59 \%$ ); the same increase in slack resources increases the probability by $6.30 \%$. In Model 6, the interaction term between private control and firm ROA was not statistically significant, but the interaction term between private control and slack resources was positive and significant $(p<$ $0.05)$. This provided partial support for Hypothesis 4B: privately controlled companies with high discretionary cash flow are more likely to issue CSR reports than are SOEs with similar resources. Model 7 included all the main effects and the interactions; the results were largely consistent with those of the reduced models.

Because we are testing interaction effects in a logit model, it is important to acknowledge the controversy regarding the validity of computing and interpreting statistically significant interactions in these models (Hoetker 2007, Norton et al. 2004). In presenting our results, we follow Greene's (2010) suggestion that researchers should conduct hypothesis testing on their model and not on predicted values. We thus present our interpretations based on our model and provide visualizations for interpretation, using the standard Aiken and West (1991) approach to plot the significant interactions. Furthermore, we have conducted robustness checks using the Stata inteff procedure (Norton et al. 2004) to verify that our inferences based on the interaction coefficients are valid. ${ }^{14}$ The interaction effects between private control and firm age and between private control and slack resources are shown in Figures 3 and 4, respectively; the patterns are consistent with our predictions.

Table 4 presents the OLS regression model of CSR reporting substantiveness. Model 1 included all the organizational and environmental controls. Models 2-4 tested the predictions of Hypotheses 5 and 6 . Hypothesis 5 predicted that firms with leaders with experience in government bureaus are more likely to engage in substantive
Figure 3 Interaction Effect Between Private Control and Firm Age on CSR Reporting

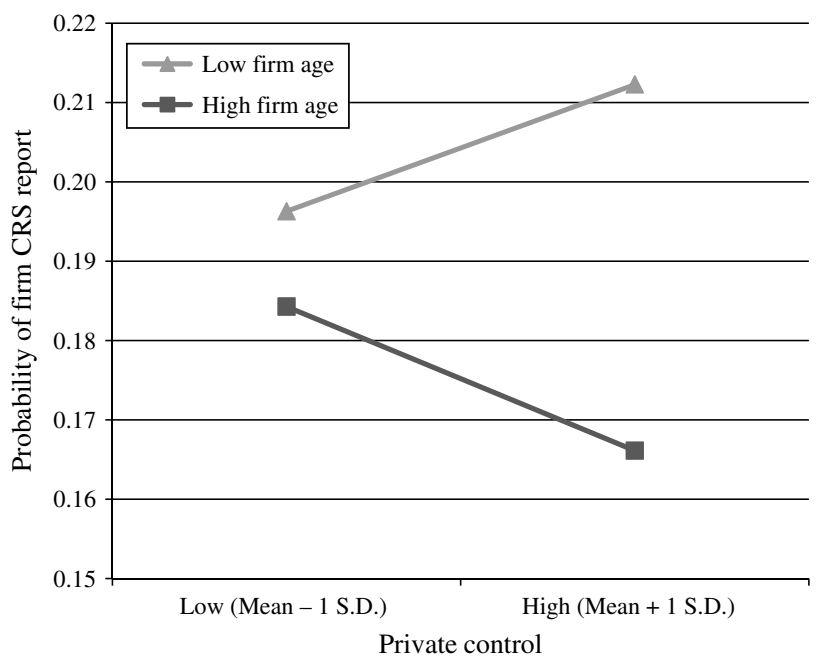

CSR reporting. In Model 2, the effect of having a CEO who is or has been a government official was marginally significant $(p<0.10)$, partially supporting Hypothesis 5 . Hypothesis 6 predicted that the level of government institutional development of the region in which the firm is headquartered would positively affect substantive CSR reporting. In Model 3, the effect of regional development was positively significant $(p<0.05)$, supporting Hypothesis 6 . Everything else being equal, a one-unit increase in regional development will increase the substantiveness of CSR reports by $13 \%$. The results were the same in Model 4, which included both independent variables.

It is worth noting that the control variables return results that are highly consistent with our theory. In the analyses examining CSR reporting probability, neither

Figure 4 Interaction Effect Between Private Control and Firm Slack Resources on CSR Reporting

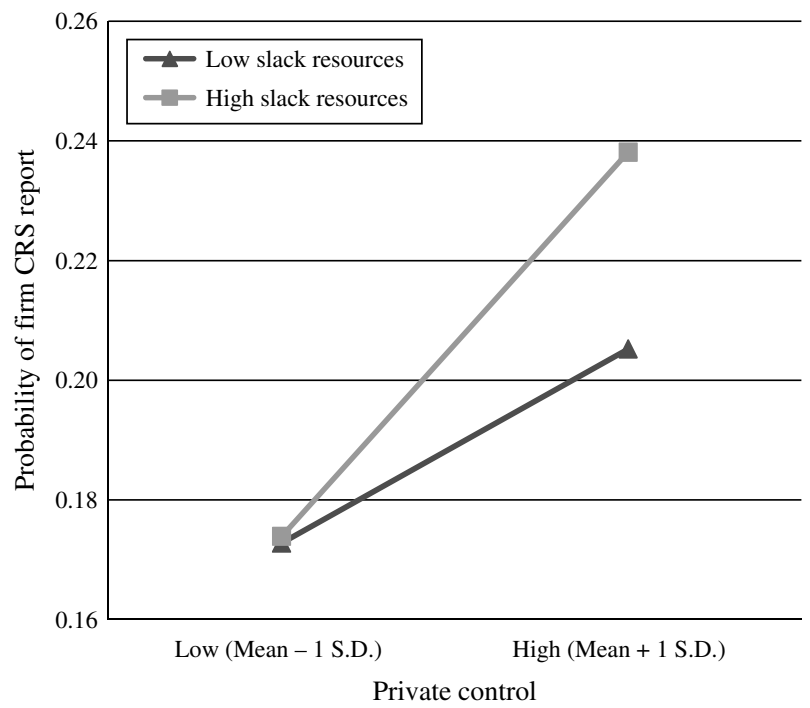


Table 4 Estimates from OLS Regression of CSR Reporting Substantiveness

\begin{tabular}{|c|c|c|c|c|}
\hline Variable & Model 1 & Model 2 & Model 3 & Model 4 \\
\hline \multicolumn{5}{|c|}{ Organizational and environmental controls } \\
\hline Firm size & $\begin{array}{l}2.927^{* * *} \\
(0.441)\end{array}$ & $\begin{array}{l}2.996 * * * \\
(0.446)\end{array}$ & $\begin{array}{l}2.819^{* * *} \\
(0.439)\end{array}$ & $\begin{array}{l}2.889 * * * \\
(0.445)\end{array}$ \\
\hline Required discloser (yes $=1$ ) & $\begin{array}{l}1.468 \\
(0.929)\end{array}$ & $\begin{array}{c}1.457 \\
(0.924)\end{array}$ & $\begin{array}{c}1.484 \\
(0.938)\end{array}$ & $\begin{array}{c}1.476 \\
(0.933)\end{array}$ \\
\hline Media exposure & $\begin{array}{c}-0.011 \\
(0.030)\end{array}$ & $\begin{array}{r}-0.014 \\
(0.031)\end{array}$ & $\begin{array}{r}-0.008 \\
(0.030)\end{array}$ & $\begin{array}{r}-0.011 \\
(0.031)\end{array}$ \\
\hline Reporting experience & $\begin{array}{l}3.444^{+} \\
(1.912)\end{array}$ & $\begin{array}{l}3.535^{+} \\
(1.908)\end{array}$ & $\begin{array}{l}3.335^{+} \\
(1.882)\end{array}$ & $\begin{array}{r}3.427^{+} \\
(1.877)\end{array}$ \\
\hline Foreign sales & $\begin{array}{c}0.004 \\
(0.018)\end{array}$ & $\begin{array}{c}0.006 \\
(0.018)\end{array}$ & $\begin{array}{c}0.002 \\
(0.018)\end{array}$ & $\begin{array}{c}0.004 \\
(0.018)\end{array}$ \\
\hline International stockholders & $\begin{array}{r}3.132^{+} \\
(1.728)\end{array}$ & $\begin{array}{r}3.130^{+} \\
(1.729)\end{array}$ & $\begin{array}{l}2.799 \\
(1.734)\end{array}$ & $\begin{array}{c}2.792 \\
(1.736)\end{array}$ \\
\hline Private control (yes $=1$ ) & $\begin{array}{l}0.362 \\
(0.934)\end{array}$ & $\begin{array}{l}0.485 \\
(0.927)\end{array}$ & $\begin{array}{l}0.159 \\
(0.933)\end{array}$ & $\begin{array}{c}0.320 \\
(0.927)\end{array}$ \\
\hline CEO NPC/CPPCC membership & $\begin{array}{c}1.228 \\
(1.290)\end{array}$ & $\begin{array}{l}0.818 \\
(1.311)\end{array}$ & $\begin{array}{c}1.321 \\
(1.288)\end{array}$ & $\begin{array}{c}0.907 \\
(1.299)\end{array}$ \\
\hline Firm age & $\begin{array}{r}-0.215^{*} \\
(0.109)\end{array}$ & $\begin{array}{r}-0.225^{*} \\
(0.110)\end{array}$ & $\begin{array}{r}-0.199^{+} \\
(0.110)\end{array}$ & $\begin{array}{r}-0.207^{+} \\
(0.111)\end{array}$ \\
\hline Firm ROA & $\begin{array}{c}4.272 \\
(10.823)\end{array}$ & $\begin{array}{c}0.679 \\
(11.195)\end{array}$ & $\begin{array}{c}3.256 \\
(10.932)\end{array}$ & $\begin{array}{c}0.420 \\
(11.267)\end{array}$ \\
\hline Slack resources & $\begin{array}{l}2.725 \\
(2.563)\end{array}$ & $\begin{array}{c}2.493 \\
(2.551)\end{array}$ & $\begin{array}{c}2.730 \\
(2.536)\end{array}$ & $\begin{array}{l}2.514 \\
(2.531)\end{array}$ \\
\hline \multicolumn{5}{|l|}{ Sociopolitical monitoring controls } \\
\hline CEO as government official & & $\begin{array}{r}1.738^{+} \\
(1.015)\end{array}$ & & $\begin{array}{c}1.761^{+} \\
(1.014)\end{array}$ \\
\hline Regional institutional development & & & $\begin{array}{r}1.532^{*} \\
(0.767)\end{array}$ & $\begin{array}{r}1.553^{*} \\
(0.762)\end{array}$ \\
\hline Constant & $\begin{array}{c}32.309^{* * * *} \\
(9.799)\end{array}$ & $\begin{array}{c}-34.538^{* * *} \\
(9.877)\end{array}$ & $\begin{array}{c}-45.337^{* * *} \\
(12.335)\end{array}$ & $\begin{array}{c}-47.816^{* * *} \\
(12.435)\end{array}$ \\
\hline No. of observations & 791 & 791 & 791 & 791 \\
\hline$F$-value & 12.53 & 10.58 & 10.27 & 9.93 \\
\hline$R^{2}$ & 0.377 & 0.380 & 0.382 & 0.385 \\
\hline
\end{tabular}

regional institutional development nor CEO as government official - the key predictors in the analyses of reporting substantiveness-was significant. These results reinforce the idea that these firms are aware that they may be under additional scrutiny and therefore issue reports only when they can engage in substantive CSR practices.

Alternatively, factors that significantly affected the likelihood of CSR reporting probability, such as firm ROA, slack resources, and CEO NPC/CPPCC membership, had no effect on the substantiveness of reporting. Also consistent with this pattern, required discloser and media exposure had positive impacts on issuing reports but had no effect on the reports' substantiveness. It may be that these factors exert pressure on a firm in such a way that they are more likely to engage in symbolic reporting. Comparing these results across models gives us confidence that firms engage in both symbolic and substantive reporting and that our theoretical model helps unpack the processes that lead to one or the other.
It is important to note as well that we controlled for other potential economic or market pressures not only to ensure that our theorized effects are net of alternative explanations but also to strengthen our claim that the government processes we established are the key relationships in this context. Neither the industry dummy variables we included (results available from the authors on request) nor the two measures of international pressure, foreign sales and international stockholders, were significant. Regarding this last set of controls, as noted, a plausible alternative set of pressures is the extent to which globalizing Chinese firms are exposed to international standards of CSR reporting and transparency (KPMG 2008). However, in accordance with our original hypotheses, our results show that it is not these factors that drive CSR decisions but factors related to firms' exposure to the domestic government.

\section{Discussion and Conclusions}

This study focused on how and why firms strategically respond to government signals on CSR. Our results point 
to a complex process, with several factors influencing political dependency, which in turn affects the likelihood that a firm will comply with government signals by issuing CSR reports. Our emerging market context, i.e., a country whose government is a substantial owner of many firms, allowed us to differentiate between government relations focused on control versus those focused on a firm's quest for greater legitimacy. We found that a number of variables that proxy firm dependence on the government-including CEO membership in political councils (the NPC or CPPCC), political legacy, and financial resources-all affect its legitimacy position and, correspondingly, the likelihood of issuing a CSR report. Although our findings on the main effect of private control were not statistically significant, a number of the other political factors tested did moderate the effect of private control on reporting, suggesting that a firm's response to government signals is not a simple process. Firms face many different pressures depending on their characteristics. One unique feature of China is that there are also strong pressures from the government on some SOEs to be global exemplars (Marquis et al. 2011). Thus, a key conclusion of our research is that the effects of government legitimacy pressures cannot be accurately identified without fully understanding how a firm's background, situation, and position affect its political dependence. We encourage future research to better understand the contingencies that affect firms' political dependence and associated pressures.

In addition to examining the issuance of a CSR report, which can be seen as primarily a symbolic act, we also examined the extent to which the likelihood of government monitoring leads firms to produce reports with greater substantive content. Here, we found that another type of government pressure, i.e., bureaucratic embeddedness (whether the CEO has experience as a government official), was a significant predictor of substantive CSR reporting. We believe this is because such ties, being much tighter than the more symbolic memberships in political councils, expose the firm to greater monitoring. A firm's location in an area with greater government institutional development also predicts more substantive CSR reporting. It is important to note that the factors that lead a firm to be more substantive in its reporting did not significantly affect the firm's likelihood of issuing a report. This suggests that such firms are aware that their political position brings them additional scrutiny and therefore only issue a report when they can issue a substantive one.

As we detail below, we believe these findings offer broader contributions to research on both corporate political strategy and institutional theory.

\section{Contributions to Research on Corporate Political Strategy}

Whereas much prior research has focused on the important mechanisms of corporate political strategy in
Western contexts (e.g., Hillman 2003), researchers are now focusing more on comparing and contrasting that corporate political strategy with those in emerging markets such as China (He and Tian 2008, Tian et al. 2009). Corporate political strategy is "not only important to better understanding firms' competitive strategies in more transparent developed nations but is particularly important to understanding the relationship-based strategies needed in developing countries" (Pearce et al. 2008, p. 494). Our setting provides a novel context in which to uncover these political processes and to illustrate an intriguing paradox in the Chinese government's control of firms. As a substantial owner of SOEs, the government issues guidelines for such enterprises, so one might expect SOEs to be on the vanguard of implementing new policies. But, in fact, our study of legitimacy and dependence argues that such signals are more likely to be followed by privately controlled firms, which our interaction effect results support. We have taken advantage of China's unique characteristics to better understand government signaling and how a firm's characteristics influence its response to signaling. We concur with Tsui (2007) that such research is crucial to developing more general, nuanced management theory that is capable of understanding organizational behavior across the globe.

Correspondingly, the focus on strategic response to government signals resonates clearly with more general institutional research showing that a key form of government influence on corporate action is the creation of legitimacy norms that signal government goals and interests (Dobbin and Sutton 1998; Dobbin et al. 1993; Edelman 1990, 1992). At a general level, one contribution of our paper is joining research on corporate political strategy (e.g., Hillman 2003, Hillman et al. 2004) and institutional research, thus identifying an important and insufficiently studied mechanism of corporate political strategy, i.e., adherence to government signals on politically legitimate behavior. We encourage future research on this topic to better understand the variety of political signals and corporate responses across the globe and how these interacting mechanisms have changed over time.

A second contribution of our paper is to unpack the implications of different types of political relationships (Hillman 2005, Siegel 2007) for firms' responses to government pressure. The main point of prior research is that firms acquire a variety of benefits (i.e., information, access, influence, and reduced uncertainty and transaction costs; see Faccio 2006, Hillman 2005) through their connections with the government. In our study, some types of connections, such as membership in the NPC or CPPCC, are more symbolic than others, and we find that they are more likely to result in correspondingly symbolic compliance. Bureaucratic embeddedness, however, may result in closer monitoring by the government, making firms more likely to engage in substantive 
CSR activity. Bureaucratic connections may thus be a double-edged sword. Whereas research has shown them to be essential for access to resources in China (Fan et al. 2007), this may come at the expense of additional government scrutiny. We also found evidence of a political imprinting process such that older firms, presumably more influenced by the earlier socialist system, were less likely to pursue CSR reporting as a political strategy.

Whereas these contributions highlight the benefits of studying this context (Tsui 2007), we also acknowledge a number of idiosyncrasies of the Chinese political system that may limit the generalizability of our results. Government-firm relations may be more important in China than in other countries (Farashahi and Hafsi 2009, Guthrie 2009) and more likely to reflect decoupling (Marquis et al. 2011). Studies have documented the importance of corporate political ties in other Asian countries (Siegel 2007) and in the United States (e.g., Hillman et al. 1999), but it would be worthwhile to examine whether our specific findings hold elsewhere. As companies globalize, understanding the variation in political mechanisms is an important research endeavor both for organizational theory and for managerial practice.

\section{Contributions to Institutional Theory}

Our research also makes important contributions to institutional theory. First, as discussed above, government signals shape definitions of legitimacy, and specific firms' responses to those signals are shaped by their dependence on the government and the likelihood of government monitoring. Regarding the latter, our identification of decoupling risk is an important contribution to understanding how and when firms adopt a symbolic strategy in response to external demands. Research has identified a decoupling gap in a variety of settings, including school curricula (Meyer and Rowan 1978), social movement communications (Elsbach and Sutton 1992), and corporate strategies (Westphal and Zajac 1994, 2001), but it has given much less consideration to the causes of organization-level variation in decoupling (Scott 2008). Contrary to research suggesting that firms' symbolic strategies are not monitored (Zajac and Westphal 2004), our results suggest that firms know they face a risk in decoupling and are less likely to do so the more likely they are to be monitored. Whereas earlier work suggested variation in decoupling based on internal firm characteristics such as CEO power and board composition (Westphal and Zajac 2001), our findings suggest variations based on the closeness of the firm's relationship with the government and on the level of government monitoring associated with that relationship. We believe it is consequential that a number of firm characteristics, including our hypothesized effects of bureaucratic embeddedness and regional government development, lead firms to be more substantive in their reporting while having no effect on the likelihood that they will issue a report in the first place. It is likely that these firms perceive that, if they do issue a report, they will be exposed to greater monitoring, so the report had better be substantive.

Our framing of this second stage of our analyses focused on the substantiveness of CSR reporting. We acknowledge that a more detailed test of the substantiveness of CSR activities would be gained by examining the activities themselves. Yet, based on our supplementary analyses, discussions with consultants, and spot-checking of the highest- and lowest-rated CSR reports, there are strong indications of a high level of agreement between a firm issuing more substantive reports and actually enacting CSR practices. To prove this connection more concretely, future research may endeavor to collect data on CSR activities directly. Furthermore, we acknowledge that because of data constraints in our analysis of reporting substantiveness, we could only examine two years of activity, which limited our statistical power. This may have resulted in weaker findings than if we had had more years of data, so we encourage future research on this topic in other settings free of this constraint.

In conclusion, we believe that introducing our idea of decoupling risk (and associated monitoring processes) to the increasingly important area of CSR reporting may have the practical benefit of highlighting an important pathway by which firms can be encouraged to act meaningfully in accordance with their purported corporate responsibility. Over the past 15 years, the number of global firms issuing CSR and sustainability reports has increased from virtually none to over 3,000 (Eccles and Krzus 2010). Yet such reporting has been criticized as a sophisticated version of greenwashing or "pinkwashing" (i.e., spreading a veneer of disclosure over a lack of actual CSR activity). CSR itself has been criticized as mostly "myth and ceremony" with little actual substance (Lyon and Maxwell 2011). Although our results support the idea that some CSR activity may be symbolic, they also suggest that increased monitoring will lead firms to truly be more socially and environmentally responsible.

\section{Acknowledgments}

The authors appreciate helpful comments from John Almandoz, Julie Battilana, Shon Hiatt, Matt Lee, Mia Raynard, Michael Sauder, Jordan Siegel, Andras Tilcsik, Mike Toffel, Danqing Wang, Zoe Yang, Lynn Yin, David Zhu, and audience members at HEC Paris, the Harvard China Sociology Workshop, the Harvard Business School International Seminar, Peking University, the University of Michigan, the Hong Kong University of Science and Technology, the Chinese University of Hong Kong, the 2010 Academy of Management Meeting, and the 2010 International Association of Chinese Management Research Meeting. 


\section{Appendix}

Table A.1. Major Government Communications Regarding Corporate Social Responsibility Activities and Reporting, 2006-2011

\begin{tabular}{lcc}
\hline Guide/standard & Date & Issuing organizati \\
\hline $\begin{array}{l}\text { 1. China corporate social } \\
\text { responsibility } \\
\text { recommended } \\
\text { standard and best } \\
\text { practice }\end{array}$ & September 2006 & $\begin{array}{c}\text { China Business } \\
\text { Council for } \\
\text { Sustainable } \\
\text { Development }\end{array}$ \\
$\begin{array}{l}\text { 2. CSR Guide for } \\
\text { companies listed on } \\
\text { the Shenzhen Stock }\end{array}$ & September 2006 & $\begin{array}{c}\text { Shenzhen Stock } \\
\text { Exchange }\end{array}$ \\
$\begin{array}{l}\text { Exchange } \\
\text { 3. Guide on social } \\
\text { responsibility of listed } \\
\text { companies }\end{array}$ & September 2006 & $\begin{array}{c}\text { Shenzhen Stock } \\
\text { Exchange }\end{array}$
\end{tabular}

4. Decisions by the Central Committee of the CPC on some major issues in building a harmonious socialist society

5. Opinions of the general office of the China Banking Regulatory Commission on strengthening the social responsibility of banking financial institutions

\section{Guidelines to} state-owned enterprises directly under the central government on fulfilling corporate social responsibilities

\section{October 2006}

May 2007

\section{China Banking \\ Regulatory}

Commission

January 2008

State-owned Assets Supervision and Administration Commission
The standard aims to build the capability for social responsibility of Chinese enterprises and provide the recommended standards and practices to Chinese enterprises for references. The standard and practices include normative suggestions (meaning that Chinese enterprises are strongly "encouraged" to obey them).

It clearly encourages listed firms to issue social responsibility reports. The guide particularly encourages firms that may have safety accidents, such as firms in the biotech industry, high-pollution industries, mining, construction, etc., to issue CSR reports. It states that the most urgent task is to build CSR laws and regulations for firms to follow.

As the third stock exchange in the world that issues a corporate social responsibility guide, the Shenzhen Stock Exchange encourages listed companies to follow the social responsibility systems outlined in the guide, and it also suggests that those companies issue corporate social responsibility reports along with their annual reports. The guide requires that CSR reports of listed companies include the following: implementation of social responsibility as it pertains to employee protection, environmental pollution, product quality, and the community; and disclosure of any gap between the company's CSR and the guide's requirements. The guide emphasizes the importance of shareholders, employees, customers, and environmental protection.

It clearly states that to build a harmonious society, China should increase the social responsibility of the citizens, business enterprises, and all kinds of other organizations.

It aims to increase banking/financial institutions' sense of social responsibility. It states that banking/financial institutions' fulfillment of their social responsibility is a must for building a harmonious society. Social responsibility is a product of the in-depth development of economic globalization, and it represents the values, language, and code of conduct commonly recognized by the governments, enterprises, and other institutions of all countries for realizing coordinated economic and social development in the course of globalization. The socialist market economy, sustainable economic development, and social progress of China all depend on enterprises increasing their sense of social responsibility.

These guidelines are proposed to comprehensively implement the spirit of the 17th CPC National Congress and the Scientific Outlook on Development and give the impetus to SOEs directly under the central government to earnestly fulfill corporate social responsibilities so as to realize a coordinated and sustainable development of enterprises, society, and the environment in all respects. Fulfilling CSRs is a practical action taken by central SOEs to apply the Scientific Outlook on Development and is an overall social requirement for central SOEs. CSR reports must be fulfilled by central SOEs to realize sustainable development and to participate in international economic cooperation.

It includes 80 criteria for corporate social responsibility in categories such as energy, environmental protection production safety, product safety, employee protection, and protection of disadvantaged social groups. It encourages business enterprises to actively involve themselves in CSR activities. 
Table A.1. (cont'd)

\begin{tabular}{|c|c|c|c|}
\hline Guide/standard & Date & Issuing organization & Key content \\
\hline $\begin{array}{l}\text { 8. Notice on } \\
\text { strengthening listed } \\
\text { companies } \\
\text { undertaking social } \\
\text { responsibilities }\end{array}$ & May 2008 & $\begin{array}{l}\text { Shanghai Stock } \\
\text { Exchange }\end{array}$ & $\begin{array}{l}\text { It first raised the concept of "social value per share," which is } \\
\text { an overall evaluation of company value from a new } \\
\text { perspective. }\end{array}$ \\
\hline $\begin{array}{l}\text { 9. Guidelines of the } \\
\text { Shanghai Stock } \\
\text { Exchange for } \\
\text { environmental } \\
\text { information disclosure } \\
\text { of listed companies }\end{array}$ & May 2008 & $\begin{array}{l}\text { Shanghai Stock } \\
\text { Exchange }\end{array}$ & $\begin{array}{l}\text { The guidelines encourage listed companies to issue CSR } \\
\text { reports and actively engage in social responsibility activities. } \\
\text { Companies that are performing well in social responsibility } \\
\text { will be given first priority to be included in the Shanghai } \\
\text { Stock Exchange corporate governance sector, which is an } \\
\text { indicator of good corporate governance of the firm. }\end{array}$ \\
\hline $\begin{array}{l}\text { 10. Guide on } \\
\text { implementation of } \\
\text { corporate social } \\
\text { responsibility among } \\
\text { foreign-funded } \\
\text { enterprises (draft) }\end{array}$ & September 2008 & $\begin{array}{l}\text { Ministry of } \\
\text { Commerce }\end{array}$ & $\begin{array}{l}\text { The guide aims to encourage foreign-funded enterprises to } \\
\text { better carry out social responsibility, increase } \\
\text { competitiveness, and achieve sustainable development. } \\
\text { According to the guide, the social responsibilities for } \\
\text { foreign-funded enterprises include (1) abiding by laws, } \\
\text { regulations, and business ethics to meet enterprise } \\
\text { operation requirements; (2) meeting the goals and } \\
\text { requirements of relevant persons of interest (e.g., generating } \\
\text { values for shareholders; creating better labor, life, and } \\
\text { development conditions for employees; paying taxes and } \\
\text { establishing a healthy and natural environment for } \\
\text { communities); and (3) contributing to the social public good. }\end{array}$ \\
\hline $\begin{array}{l}\text { 11. Circular on properly } \\
\text { handling the } 2008 \\
\text { annual reports of listed } \\
\text { companies }\end{array}$ & December 2008 & $\begin{array}{l}\text { Shanghai Stock } \\
\text { Exchange }\end{array}$ & $\begin{array}{l}\text { According to this circular, three types of firms are required to } \\
\text { issue CSR reports: firms in the "corporate governance } \\
\text { group," firms listed in foreign stock exchanges, and firms in } \\
\text { financial industries. }\end{array}$ \\
\hline $\begin{array}{l}\text { 12. Guideline for the } \\
\text { preparation of the } \\
\text { report on performance } \\
\text { of CSR }\end{array}$ & January 2009 & $\begin{array}{c}\text { Shanghai Stock } \\
\text { Exchange }\end{array}$ & $\begin{array}{l}\text { It states the rules of preparation for CSR reports in social, } \\
\text { environmental, and economic sustainable development } \\
\text { contexts. The rules are consistent with the international } \\
\text { standard GRI } 3.0 \text { in structure. }\end{array}$ \\
\hline $\begin{array}{l}\text { 13. Application } \\
\text { Guidelines for } \\
\text { Enterprise Internal } \\
\text { Control No. } 4 \text {-Social } \\
\text { Responsibilities }\end{array}$ & May 2010 & $\begin{array}{l}\text { Accountancy } \\
\text { Department of } \\
\text { the Ministry of } \\
\text { Finance }\end{array}$ & $\begin{array}{l}\text { The guidelines state that corporate social responsibility } \\
\text { includes items such as safety production, product quality, } \\
\text { environmental protection, resource saving, a high } \\
\text { employment rate, and protection of employee rights. }\end{array}$ \\
\hline $\begin{array}{l}\text { 14. Opinions on } \\
\text { encouraging industrial } \\
\text { enterprises to engage } \\
\text { in social } \\
\text { responsibilities }\end{array}$ & May 2011 & $\begin{array}{l}\text { All-China } \\
\text { Federation of } \\
\text { Industrial } \\
\text { Economics }\end{array}$ & $\begin{array}{l}\text { It aims to strengthen the social responsibility of industrial } \\
\text { enterprises and improve the social awareness of industrial } \\
\text { enterprises at the national level. }\end{array}$ \\
\hline $\begin{array}{l}\text { 15. Charity development } \\
\text { guide platform } \\
\text { (2011-2015) }\end{array}$ & July 2011 & $\begin{array}{l}\text { Ministry of Civil } \\
\text { Affairs }\end{array}$ & $\begin{array}{l}\text { "China will encourage more transparency in its charitable } \\
\text { organizations over the next five years by increasing the } \\
\text { amount of data it publishes on the organizations and inviting } \\
\text { the public to supervise them.... In its five-year guideline for } \\
\text { the development of China's charitable organizations, the } \\
\text { Ministry of Civil Affairs said that transparency will be a 'basic } \\
\text { principle' in developing charity work while promising to } \\
\text { respect the will of donors.... To lend credibility to charitable } \\
\text { organizations, information regarding the management and } \\
\text { use of donations will be published and subject to } \\
\text { supervision from both the government and the public, } \\
\text { according to the guideline. Donors will be able to decide for } \\
\text { themselves the size of their donations and how they want to } \\
\text { have their donations used, the guideline said. In addition, } \\
\text { donors from overseas will be allowed to have import tariffs or } \\
\text { value-added taxes cut or exempted in according [sic] with } \\
\text { laws and relevant administrative regulations" } \\
\text { (Xinhuanet.com 2011). }\end{array}$ \\
\hline
\end{tabular}


Table A.1. (cont'd)

\begin{tabular}{|c|c|c|c|}
\hline Guide/standard & Date & Issuing organization & Key content \\
\hline $\begin{array}{l}\text { 16. Principles of } \\
\text { sustainable } \\
\text { development of } \\
\text { state-owned } \\
\text { enterprises during } \\
\text { 12th Five-Year Plan } \\
\text { period }\end{array}$ & September 2011 & $\begin{array}{l}\text { State-owned Assets } \\
\text { Supervision and } \\
\text { Administration } \\
\text { Commission }\end{array}$ & $\begin{array}{l}\text { The guide proposes that sustainable development should be } \\
\text { the core of corporate social responsibilities, and state-owned } \\
\text { enterprises should be harmonious in development with } \\
\text { society and the environment. The state-owned enterprises } \\
\text { should be a role model for social responsibility. }\end{array}$ \\
\hline
\end{tabular}

Note. We have reported examples beyond our observation period (2006-2009) to show that the Chinese government continues to issue legitimacy guidelines on the focal issue.

\section{Endnotes}

${ }^{1}$ Note that almost all of these communications between the government and business enterprises have used terms such as "guidelines/guide” (指引/指南), “opinions” (意见), “recommended practices" (范例), and “outlines" (纲要) and have almost never used terms such as "policies" (政策) and “enforcement/regulations” (规定). So although these communications are not explicitly coercive, the government signal is clear: enterprises are encouraged to engage in CSR activities. ${ }^{2}$ We acknowledge that issuing more detailed reports could just be a more elaborate form of decoupling whereby firms fabricate the specific details of their CSR activities. Below, we discuss some supplementary research and analysis suggesting that assessing the level of detail and substance of the CSR report does correspond to substantive CSR implementation. ${ }^{3}$ Before these reforms, the financial organization of the Communist state was highly centralized, even more so than in other Communist countries (Walder 2000). Industrial investment, savings rates, the extraction of economic value, and the prices of products and services were all controlled by the central planning system.

${ }^{4}$ To further verify that using the RKS data was a valid way to assess the substantiveness of CSR reporting, we investigated the CSR activities and reporting (from the firm's websites and press releases as well as from its CSR report) of the five highest-scoring and five lowest-scoring firms. For example, the Ping'an report, which earned the highest score of all the 2009 reports, included detailed systematic information about the firm's CSR activities. The report that earned the lowest evaluation discussed only the firm's CSR activities generally and briefly. We also checked correlations between each RKS rating and two other indications of CSR report substantiveness: page count and the use of GRI 3.0 guidelines. The correlations were 0.82 and 0.60 , respectively, which provided convergent validity for our measure. Finally, we interviewed consultants at two CSR consulting firms (one China-based and one international) that help firms produce CSR reports. We showed them the RKS list of items and methodology and asked if they felt that higher scores would be reliable indicators of more substantive CSR activity. Both felt that, because of the specificity of the items measured, they were virtually certain that such reporting indicated greater CSR implementation. These investigations left us confident that the RKS data are a valid representation of the substantiveness of CSR reporting.

${ }^{5}$ In robustness checks, we also used a continuous variable of the ownership percentage. The results are consistent with what we present in the paper, except that one of the interaction effects becomes marginally significant. Results are available from the authors on request.

${ }^{6}$ In previous research, the concept of a CEO's political connection was measured by a dummy variable equal to 1 if the CEO was either a member of the NPC or the CPPCC or a government official (Fan et al. 2007, Li et al. 2006). However, our theoretical approach distinguishes between membership in political congresses and bureaucratic embeddedness.

${ }^{7}$ The corporate governance group was initiated by the Shanghai Stock Exchange to promote better corporate governance structure. Corporations on the exchange can apply to be included. Applications are evaluated and either accepted or rejected by a special committee organized by the exchange. In general, companies in this group are thought to have better governance practices.

${ }^{8}$ Note that just because a firm's characteristics suggest it would be required to issue a report does not mean that the firm did so. In our sample, of the firms that were required to issue a report in a given year, $31 \%$ did not. Excluding required firms from the analysis of firms issuing CSR reports did not change the results.

${ }^{9}$ Because including $Y_{t-1}$ as a regressor could create an autocorrelation risk, as a robustness check, we ran the models without $Y_{t-1}$ and obtained similar results.

${ }^{10}$ These categories are agriculture, forestry, livestock farming, fishery; mining; manufacturing; electric power, gas, and water production and supply; construction; transport and storage; information technology; wholesale and retail trade; finance and insurance; real estate; social service; communication and culture; and others.

${ }^{11}$ In supplementary analyses, we examined whether different types of industries were more likely to issue CSR reports or to provide more substantive reports. Of particular interest were those industries that are more closely connected to the government, for example, by being more regulated. However, these investigations did not produce any statistically significant relationships.

${ }^{12}$ We conducted two alternative specifications as robustness checks. First, we ran random effects models (xtlogit and xtreg) as an alternative way to control for multiple observations per firm. Results were identical to those we report. (We were unable to implement fixed effects because of the limited number of observations per firm and because some of our variables are time-invariant.) We used the standard logit and OLS models with robust standard errors for ease of interpretation. Furthermore, we also estimated these two analyses as a two-stage Heckman selection model (Heckman 1979) with the variable 
stock market exchange as the instrument. Significance levels of hypothesized coefficients and resulting interpretations are identical. This is a potentially valid way to test our predictions because our two dependent variables are interrelated in such a way that the rating of CSR reporting substantiveness is contingent on whether the focal firm has issued a CSR report. Furthermore, it is arguable that stock market exchange serves as a valid instrument because, during our time period, the two stock exchanges had different policies and guidelines on whether a firm should report, but neither made specific requirements about the quality of the reports. These results are available from the authors on request.

${ }^{13}$ Note that this is only $83 \%$ of the 954 CSR reports that have been issued since 2006 because the RKS data are only available for 2008 and 2009.

${ }^{14}$ Further robustness checks with the inteff procedure in Stata indicate that the coefficients of the interaction term between private control and firm age and the interaction term between private control and slack resources were both statistically significant (Hoetker 2007, Norton et al. 2004), which provides further evidence that our results are robust.

\section{References}

Aiken LS, West SG (1991) Multiple Regression: Testing and Interpreting Interactions (Sage, Newbury Park, CA).

Bai CE, Lu J, Tao Z (2006) Property rights protection and access to bank loans. Econom. Transition 14(4):611-628.

Barnett ML (2007) Stakeholder influence capacity and the variability of financial returns to corporate social responsibility. Acad. Management Rev. 32(3):794-816.

Baron DP (1995) Integrated strategy: Market and nonmarket components. Calif. Management Rev. 37(2):47-65.

Bonardi JP, Hillman AJ, Keim GD (2005) The attractiveness of political markets: Implications for firm strategy. Acad. Management Rev. 30(2):397-413.

Bonardi JP, Holburn GLF, Bergh RGV (2006) Nonmarket strategy performance: Evidence from U.S. electric utilities. Acad. Management J. 49(6):1209-1228.

Brandt L, Li H (2003) Bank discrimination in transition economies: Ideology, information, or incentives? J. Comparative Econom. 31(3):387-413.

Brown AD (1998) Narrative, politics and legitimacy in an IT implementation. J. Management Stud. 35(1):35-58.

Campbell JL (2007) Why would corporations behave in socially responsible ways? An institutional theory of corporate social responsibility. Acad. Management Rev. 32(3):946-967.

Carow K, Heron R, Saxton T (2004) Do early birds get the returns? An empirical investigation of early-mover advantages in acquisitions. Strategic Management J. 25(6):563-585.

Chen W (2007) Does the color of the cat matter? The red hat strategy in China's private enterprises. Management Organ. Rev. 3(1):55-80.

ChinaCSR.com (2009) How far can Chinese companies take corporate social responsibility? (February 23) http://www.chinacsr .com/en/2009/02/23/4572-how-far-can-chinese-companies-takecorporate-social-responsibility/.

China WTO Tribune (2009) Four discoveries of the research on CSR reports in China from 2001 to 2009. [In Chinese.] (December 2) http://www.wtoguide.net/Html/tbgz/06122515571068955091271 627382793311.html.
Deephouse D, Suchman MC (2008) Legitimacy in organizational Institutionalism. Greenwood R, Oliver C, Suddaby R, SahlinAndersson K, eds. The Sage Handbook of Organizational Institutionalism (Sage, London), 49-77.

Dickson BJ (2003) Red Capitalists in China: The Party, Private Entrepreneurs, and Prospects for Political Change (Cambridge University Press, Cambridge, UK).

Dobbin F, Sutton FR (1998) The strength of a weak state: The rights revolution and the rise of human resources management divisions. Amer. J. Sociol. 104(2):441-476.

Dobbin F, Schrage D, Kalev A (2009) Someone to watch over me: Coupling, decoupling, and unintended consequences in corporate equal opportunity. Working paper, Harvard University, Cambridge, MA.

Dobbin F, Sutton J, Meyer J, Scott WR (1993) Equal opportunity law and the construction of internal labor markets. Amer. J. Sociol. 99:396-427.

Eccles RG, Krzus MP (2010) One Report: Integrated Reporting for a Sustainable Strategy (John Wiley \& Sons, Hoboken, N.J).

Edelman LB (1990) Legal environments and organizational governance: The expansion of due process in the American workplace. Amer. J. Sociol. 95:1401-1440.

Edelman LB (1992) Legal ambiguity and symbolic structures: Organizational mediation of civil rights law. Amer. J. Sociol. 97:1531-1576.

Edelman LB, Suchman MC (1997) The legal environments of organizations. Annual Rev. Sociol. 23:479-515.

Elsbach KD, Sutton RI (1992) Acquiring organizational legitimacy through illegitimate actions: A marriage of institutional and impression management theories. Acad. Management J. 35(4):699-738.

Faccio M (2006) Politically connected firms. Amer. Econom. Rev. 96(1):369-386.

Faccio M, Lang LHP (2002) The ultimate ownership of Western European corporations. J. Financial Econom. 65(3):365-395

Faccio M, Masulis RW, McConnell JJ (2006) Political connections and corporate bailouts. J. Finance 61(6):2597-2635.

Fan JPH, Wong TJ, Zhang T (2007) Politically connected CEOs, corporate governance, and post-IPO performance of China's newly partially privatized firms. J. Financial Econom. 84(2):330-357.

Farashahi M, Hafsi T (2009) Strategy of firms in unstable institutional environments. Asia Pacific J. Management 26(4):643-666.

Goldstein SM (1995) China in transition: The political foundations of incremental reform. China Quart. 144:1105-1131.

Greene W (2010) Testing hypotheses about interaction terms in nonlinear models. Econom. Lett. 107(2):291-296.

Guthrie D (2009) China and Globalization: The Social, Economic and Political Transformation of Chinese Society, revised ed. (Routledge, New York).

He Y, Tian Z (2008) Government-oriented corporate public relation strategies in transitional China. Management Organ. Rev. 4(3):367-391.

Heckman JJ (1979) Sample selection bias as a specification error. Econometrica 47(1):153-161.

Hiatt S, Park S (2013) Lords of the harvest: Third-party influence and regulatory approval of genetically modified organisms. Acad. Management J. 56(4):923-944.

Hillman AJ (2003) Determinants of political strategies in U.S. multinationals. Bus. Soc. 42(4):455-484. 
Hillman AJ (2005) Politicians on the board of directors: Do connections affect the bottom line? J. Management 31(3):464-481.

Hillman AJ, Keim GD, Schuler D (2004) Corporate political activity: A review and research agenda. J. Management 30(6):837-857.

Hillman AJ, Zardkoohi A, Bierman L (1999) Corporate political strategies and firm performance: Indications of firm-specific benefits from personal service in the U.S. government. Strategic Management J. 20(1):67-81.

Hitt MA, Hoskisson RE, Kim H (1997) International diversification: Effects on innovation and firm performance in productdiversified firms. Acad. Management J. 40(4):767-798.

Hoetker G (2007) The use of logit and probit models in strategic management research: Critical issues. Strategic Management J. 28(4):331-343.

Hong Z (2004) Mapping the evolution and transformation of the new private entrepreneurs in China. J. Chinese Political Sci. 9(1):23-42.

Huang Y (2008) Capitalism with Chinese Characteristics: Entrepreneurship and the State (Cambridge University Press, Cambridge, New York).

Kogut B, Zander U (2000) Did socialism fail to innovate? A natural experiment of the two Zeiss companies. Amer. Sociol. Rev. 65(2):169-190.

KPMG (2008) KPMG international survey of corporate responsibility reporting 2008. Report, KPMG International, Amsterdam. http://www.kpmg.com/EU/en/Documents/KPMG_International _survey_Corporate_responsibility_Survey_Reporting_2008.pdf.

Kriauciunas A, Kale P (2006) The impact of socialist imprinting and search on resource change: A study of firms in Lithuania. Strategic Management J. 27(7):659-679.

La Porta R, Lopez-de-Silanes F, Shleifer A (1999) Corporate ownership around the world. J. Finance 54(2):471-518.

La Porta R, Lopez-de-Silanes F, Shleifer A, Vishny R (1998) Law and finance. J. Political Econom. 106:1113-1155.

Li J, Qian C (2013) Principal-principal conflicts under weak institutions: A study of corporate takeovers in China. Strategic Management J. 34(4):498-508.

Li H, Zhang Y (2007) The role of managers' political networking and functional experience in new venture performance: Evidence from China's transition economy. Strategic Management J. 28(8):791-804.

Li H, Meng L, Zhang J (2006) Why do entrepreneurs enter politics? Evidence from China. Econom. Inquiry 44(3):559-578.

Li H, Meng L, Wang Q, Zhou LA (2008) Political connections, financing and firm performance: Evidence from Chinese private firms. J. Development Econom. 87(2):283-299.

Lin LW (2010) Corporate social responsibility in China: Window dressing or structural change? Berkeley J. Internat. Law 28(1):64-100

Lord MD (2000) Corporate political strategy and legislative decision making: The impact of corporate legislative influence activities. Bus. Soc. 39(1):76-93.

Luo Y (2003) Industrial dynamics and managerial networking in an emerging market: The case of China. Strategic Management J. 24(13):1315-1327.

Lyon TP, Maxwell JW (2011) Greenwash: Environmental disclosure under threat of audit. J. Econom. Management Strategy 20(1):3-41.
Ma D, Parish WL (2006) Tocquevillian moments: Charitable contributions by Chinese private entrepreneurs. Soc. Forces 85(2):943-964.

Marquis C, Huang Z (2010) Acquisitions as exaptation: The legacy of founding institutions in the U.S. commercial banking industry. Acad. Management J. 53(6):1441-1473.

Marquis C, Tilcsik A (2013) Imprinting: Toward a multi-level theory. Acad. Management Ann. 7(1):193-243.

Marquis C, Yin L, Yang D (2011) COSCO: Implementing sustainability HBS Case 412081, Harvard Business School, Boston.

Marquis C, Zhang J, Zhou Y (2011) Regulatory uncertainty and corporate responses to environmental protection in China. Calif. Management Rev. 54(1):39-63.

Marquis C, Dai N, Yang D, Wu H (2010) State grid: Corporate social responsibility HBS Case 410141, Harvard Business School, Boston.

Meyer JW, Rowan B (1977) Institutionalized organizations: Formal structure as myth and ceremony. Amer. J. Sociol. 83(2):340-363.

Meyer MW, Rowan B (1978) The structure of educational organizations. Meyer MW et al., eds. Environments and Organizations, 1st ed. (Jossey-Bass, San Francisco), 78-109.

Mizruchi MS (1992) The Structure of Corporate Political Action: Interfirm Relations and Their Consequences (Harvard University Press, Cambridge, MA).

Naughton B (2007) The Chinese Economy: Transitions and Growth (MIT Press, Cambridge, MA).

Nee V (1992) Organizational dynamics of market transition: Hybrid forms, property rights, and mixed economy in China. Admin. Sci. Quart. 37(1):1-27.

Norton EC, Wang H, Ai C (2004) Computing interaction effects and standard errors in logit and probit models. Stata J. 4(2):154-167.

O'Brien KJ (1990) Reform Without Liberalization: China's National People's Congress and the Politics of Institutional Change (Cambridge University Press, New York).

Okhmatovskiy I, David RJ (2012) Setting your own standards: Internal corporate governance codes as a response to institutional pressure. Organ. Sci. 23(1):155-176.

Oliver C (1991) Strategic responses to institutional processes. Acad. Management Rev. 16(1):145-179.

Oliver C, Holzinger I (2008) The effectiveness of strategic political management: A dynamic capabilities framework. Acad. Management Rev. 33(2):496-520.

Park S, Sine WD, Tolbert PS (2011) Professions, organizations, and institutions: Tenure systems in colleges and universities. Work Occupations 38(3):340-371.

Pearce JL, De Castro JO, Guillen MF (2008) Influencing politics and political systems: Political systems and corporate strategies (introduction to special topic forum). Acad. Management Rev. 33(2):493-495.

Peng MW, Heath PS (1996) The growth of the firm in planned economies in transition: Institutions, organizations, and strategic choice. Acad. Management Rev. 21(2):492-528.

Peng MW, Luo Y (2000) Managerial ties and firm performance in a transition economy: The nature of a micro-macro link. Acad. Management J. 43(3):486-501.

Peng Y (2004) Kinship networks and entrepreneurs in China's transitional economy. Amer. J. Sociol. 109(5):1045-1074.

Pfeffer J, Salancik G (1978) The External Control of Organizations (Harper \& Row, New York) 
Quasney TJ (2003) Competitive interaction: A study of market, nonmarket and integrated competitive behavior. Unpublished doctoral dissertation, University of Maryland, College Park.

Ryan TP (1997) Modern Regression Methods (John Wiley \& Sons, New York).

Saich T (2001) Governance and Politics of China (Palgrave, New York).

Schuler DA, Rehbein K (1997) The filtering role of the firm in corporate political involvement. Bus. Soc. 36(2):116-139.

Schuler DA, Rehbein K, Cramer RD (2002) Pursuing strategic advantage through political means: A multivariate approach. Acad. Management J. 45(4):659-672.

Scott WR (2001) Institutions and Organizations, 2nd ed. (Sage, Thousand Oaks, CA).

Scott WR (2008) Institutions and Organizations: Ideas and Interests, 3rd ed. (Sage, Los Angeles).

See G (2009) Harmonious society and Chinese CSR: Is there really a link? J. Bus. Ethics 89:1-22.

Seifert B, Morris SA, Bartkus BR (2004) Having, giving, and getting: Slack resources, corporate philanthropy, and firm financial performance. Bus. Soc. 43(2):135-161.

Short JL, Toffel MW (2010) Making self-regulation more than merely symbolic: The critical role of the legal environment. Admin. Sci. Quart. 55(3):361-396.

Siegel J (2007) Contingent political capital and international alliances: Evidence from South Korea. Admin. Sci. Quart. 52(4):621-666.

Sino-Swedish CSR Cooperation (2009) Interpreting CSR policy for large Chinese SOEs. Press release (May 14), http://csr2.mofcom .gov.cn/article/laws/200905/20090506246453.shtml.

Stinchcombe AL (1965) Social structure and organizations. March JG, ed. Handbook of Organizations (Rand McNally \& Co., Chicago), 142-193.

Tian Z, Hafsi T, Wu W (2009) Institutional determinism and political strategies. Bus. Soc. 48(3):284-325.

Tilcsik A (2010) From ritual to reality: Demography, ideology, and decoupling in a post-Communist government agency. Acad. Management J. 53(6):1474-1498.

Tsui AS (2007) From homogenization to pluralism: International management research in the academy and beyond. Acad. Management J. 50(6):1353-1364.

Waddock SA, Graves SB (1997) The corporate social performancefinancial performance link. Strategic Management $J$. 18(4):303-319.

Walder AG (1995) Local governments as industrial firms: An organizational analysis of China's transitional economy. Amer. J. Sociol. 101(2):263-301.

Walder AG (2000) China's transitional economy. Li JT, Tsui AS, Weldon E, eds. Management and Organizations in the Chinese Context (St. Martin's Press, New York), 63-83.
Wang H, Qian C (2011) Corporate philanthropy and corporate financial performance: The roles of stakeholder response and political access. Acad. Management J. 54(6):1159-1181.

Wang H, Choi J, Li J (2008) Too little or too much? Untangling the relationship between corporate philanthropy and firm financial performance. Organ. Sci. 19(1):143-159.

Wang Q, Wong TJ, Xia L (2008) State ownership, the institutional environment, and auditor choice: Evidence from China. J. Accounting Econom. 46(1):112-134.

Westphal JD, Zajac EJ (1994) Substance and symbolism in CEOs' long-term incentive plans. Admin. Sci. Quart. 39(3):367-390.

Westphal JD, Zajac EJ (1995) Who shall govern? CEO/Board power, demographic similarity, and new director selection. Admin. Sci. Quart. 40(1):60-83.

Westphal JD, Zajac EJ (2001) Decoupling policy from practice: The case of stock repurchase programs. Admin. Sci. Quart. 46(2):202-228.

Xinhuanet.com (2011) Chinese ministry vows more transparency for charitable organizations. (July 15) http://news.xinhuanet.com/ english2010/china/2011-07/15/c_13988257.htm.

Yin G, Li W, Yu Z, Zheng R, Li W (2008) How to Write a CSR Report, Chinese ed. (Golden Bee Development Center for Chinese CSR/China WTO Tribune, Beijing).

Young MN, Peng MW, Ahlstrom D, Bruton GD, Jiang Y (2008) Corporate governance in emerging economies: A review of the principal-principal perspective. J. Management Stud. 45(1):196-220.

Zajac EJ, Westphal JD (2004) The social construction of market value: Institutionalization and learning perspectives on stock market reactions. Amer. Sociol. Rev. 69(3):433-457.

Zhong HW (2009) Guidelines of Chinese Firms' Social Reporting (CASS-CSR 1.0) (Economy and Management Publishing, Beijing).

Christopher Marquis is an associate professor in the Organizational Behavior unit at the Harvard Business School. His research is focused on how firm behavior is shaped by broader contexts such as embeddedness in geographic communities and how environmental conditions during founding periods leave a lasting imprint on organizations. He is exploring these issues in the context of the global corporate social responsibility and how environmental sustainability initiatives have developed in China.

Cuili Qian is an assistant professor in the management department at the College of Business, City University of Hong Kong. Her current research focuses on corporate stakeholders and social responsibility, corporate political strategies, and corporate governance. She is exploring these issues in the context of transition economies, particularly in China. 